\title{
FOSSILIZATION MODEL FOR SQUAMASTROBUS TIGRENSIS FOLIAGE IN A VOLCANIC-ASH DEPOSIT: IMPLICATIONS FOR PRESERVATION AND TAPHONOMY (PODOCARPACEAE, LOWER CRETACEOUS, ARGENTINA)
}

\author{
MAITEN A. LAFUENTE DIAZ, ${ }^{1}$ JOSÉ A. D’ANGELO ${ }^{2,3}$ GEORGINA M. DEL FUEYO, ${ }^{1}$ AND ERWIN L. ZODROW ${ }^{3}$ \\ ${ }^{1}$ Museo Argentino de Ciencias Naturales "Bernardino Rivadavia"-CONICET, Avda. Ángel Gallardo 470, C1405DJR Ciudad Autónoma de Buenos Aires, Argentina \\ ${ }^{2}$ IANIGLA-CCT-CONICET-MENDOZA, Área de Química, FCEN, Universidad Nacional de Cuyo, M5502JMA, Mendoza, Argentina \\ ${ }^{3}$ Palaeobotanical Laboratory, Cape Breton University, Sydney, Nova Scotia B1P 6L2, Canada \\ email: maitenlafuentediaz@gmail.com
}

\begin{abstract}
The present study is a holistic approach to the relationship between volcaniclastic host rock characteristics and the fossilization processes of short leafy coniferous branches of Squamastrobus tigrensis, preserved as fossilized-cuticles (Lower Cretaceous, Baqueró Group, Patagonia, Argentina). The question of diagenetic influences of Aptian volcaniclastic sedimentation on preservation chemistry and taphonomic processes is addressed. Whereas infrared spectroscopy provided chemical information on the leaves, vitrinite reflectance and complementary thermal indicators provided data on the thermal maturity of the dispersed organic matter in the host rock. Three sample types were analyzed: fossilized-cuticle, macerated fossilized-cuticle (by infrared spectroscopy), and associated organic host rock matter (by light microscopy). Results clearly show chemical variability between, and within the fossilized-cuticle and cuticle, as well as a similarity to type I/II kerogen, i.e., high contents of both aliphatic groups and oxygencontaining compounds. Combined with the lower maturity of the host rock, the importance of the depositional environment during burial and taphonomic conditions that affected the fossilization of $S$. tigrensis are summarized in a general fossilization model.
\end{abstract}

\section{INTRODUCTION}

Paleobiochemical information of coalified compressions and cuticles from Argentina is poorly understood. Exceptions include plant fossil remains recovered mainly from the Triassic of Mendoza (central-western Argentina), where taxa, such as Johnstonia coriacea Walkom, Johnstonia stelzneriana Frenguelli, and Dicroidium odontopteroides Gothan were chemically studied using infrared spectroscopy (e.g., D'Angelo 2004, 2006; D'Angelo and Marchevsky 2004; Zodrow et al. 2009; D'Angelo et al. 2011; D'Angelo and Zodrow 2018). Limited semi-quantitative determinations of functional groups without a chemometric interpretation were carried out on Squamastrobus tigrensis Archangelsky and Del Fueyo from the Lower Cretaceous of Patagonia in southern Argentina by Almendros et al. (1999). The aim of the present work is to obtain semi-quantitative information based on the infrared analysis of foliar compressions with well-preserved cuticles of the Cretaceous (120 Mya) S. tigrensis in order to improve the chemical knowledge of this fossil taxon. A larger number of specimens, including the two sample types of fossilized cuticles and cuticles, allowed us to obtain qualitative and, most importantly, the first semi-quantitative IR-derived data. The semi-quantitative data were evaluated by methods of principal component analysis, and comparisons could be made between fossilized cuticles and cuticles in terms of chemical functional groups present in this Patagonian taxon. For a better understanding of the overall chemical process leading to the preservation of $S$. tigrensis, dispersed organic matter in host rock samples was analyzed. The latter included the determination of maceral groups, amorphous organic matter, and thermal maturity indices.

MATERIALS AND METHODS

Specimens of Squamastrobus tigrensis (Cretaceous conifer) were collected by S. Archangelsky, R. Cúneo, and T.N. Taylor in February
1985. Samples were recovered from the world-renowned Baqueró Group (Santa Cruz Province, Argentina; Fig. 1), where a richly diverse plant assemblage includes impressions and compressions, mainly coalified, with exceptionally well-preserved cuticles. The latter allowed the establishment of several new taxa through detailed micromorphological and ultrastructural studies carried out using light and electron microscopies (Archangelsky 1991, 2003; Del Fueyo et al. 2007). In the Baqueró Group, conifers are represented by four families: Araucariaceae, Cupressaceae, Cheirolepidiaceae, and the taxonomically most diverse the Podocarpaceae. This Family is represented by dispersed pollen grains, vegetative, and fertile remains (for more details see Del Fueyo et al. 2007 and Archangelsky and Del Fueyo 2010).The Podocarpaceae is documented, among other plant fossils, by fertile remains of $S$. tigrensis, which is the only taxon characterized by leafy branches organically attached to both pollen and seed cones (Archangelsky and Del Fueyo 1989). The branches with scale-like Brachyphyllum-type leaves (Fig. 2A) have laterally and terminally attached elongate pollen and seed cones, respectively (Fig. 2B, 2C), where the microsporangia contain pollen grains of Podocarpidites type (Fig. 2D). Leaves are sessile, leathery in appearance, with a rostrate to obtuse apex and entire margin, helically arranged on the branches. Leaves are amphistomatic with stomata arranged in well-defined longitudinal rows in the abaxial cuticle, whereas those in the adaxial epidermis are arranged in undefined rows (Fig. 2E-2I). The stomatal apparatus is monocyclic to imperfectly dicyclic and composed mostly of four to five subsidiary cells. Guard cells are kidney shaped and preserved in most stomata. Remains of hypodermal cells are also observed (Fig. 2J).

\section{Materials}

The material comprised eleven rock samples that were used for both micromorphological and FTIR analyses. In addition, two host rock 


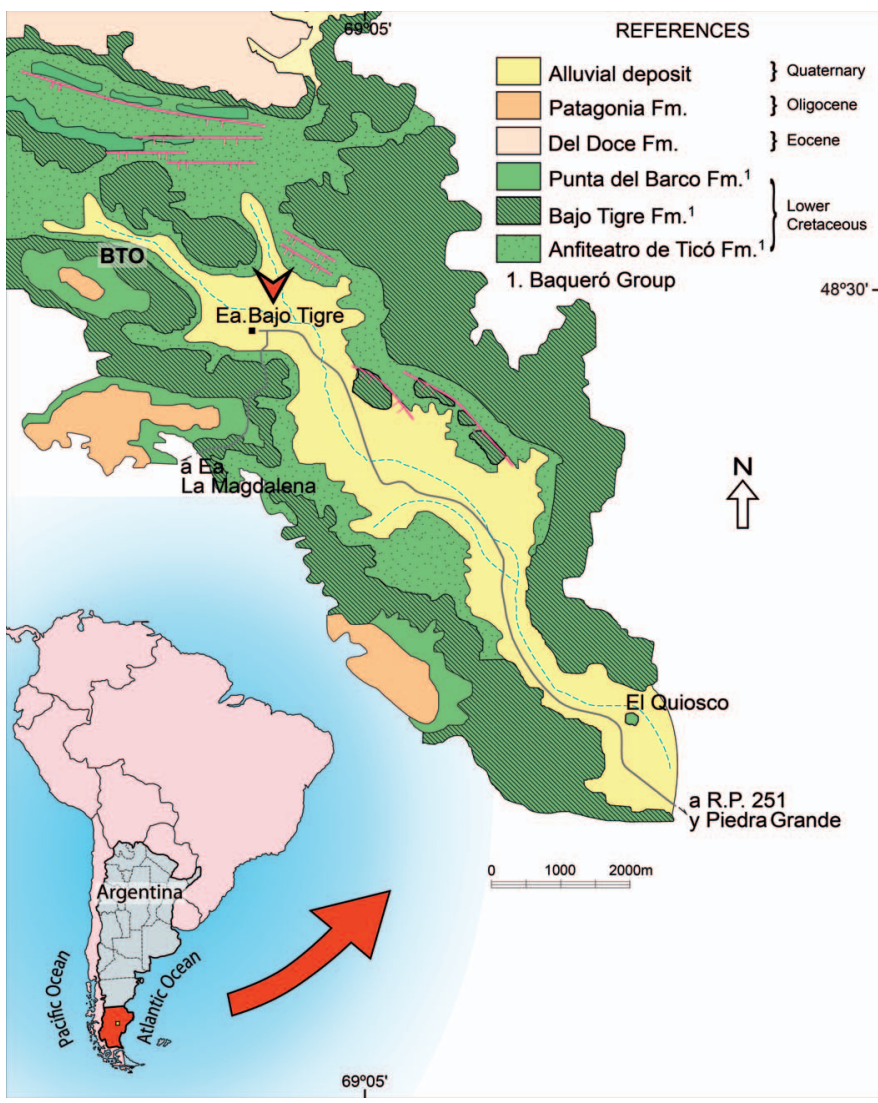

FIG. 1.-Location map showing the Bajo Tigre locality (arrowhead) and the BTO fossiliferous level in Santa Cruz Province, Argentina (modified from Cladera et al. 2002).

samples, named V1 and V2 corresponding to $\mathrm{BA} \mathrm{Pb} 11581$ and 11588 respectively, were collected from the same fossiliferous level as $S$. tigrensis. Determined from V1 and V2 were the vitrinite reflectance $\left(\mathrm{R}_{\mathrm{O}} \%\right)$ and additional maturity indices including thermal alteration index and, derived from the latter, vitrinite reflectance equivalent (TAI and VRE respectively). The Ro\% analysis was carried out in accordance with ASTM standard procedure D7708-14 (ASTM 2014).

The fossil specimens and slides for light microscopy (LM) and scanning electron microscopy (SEM) were deposited in the Paleobotany Collection of the Museo Argentino de Ciencias Naturales "Bernardino Rivadavia" under the acronyms: $\mathrm{BA} \mathrm{Pb}(7681,11311$, and 113241), BA Pb Pm (648 and 655) and BA Pb MEB (580, 584, and 585). The samples used for FTIR spectroscopy analysis were deposited in the Paleobotany Collection of the Museo Argentino de Ciencias Naturales "Bernardino Rivadavia" under the acronyms: $\mathrm{BA} \mathrm{Pb}(7678,11321,11324,11333,11583,11584,11585$, and 11586). In addition, the material used for $\mathrm{R}_{\mathrm{O}} \%$, and other thermal maturity analyses were deposited in the Paleobotany Collection of the Museo Argentino de Ciencias Naturales "Bernardino Rivadavia" under the acronyms $\mathrm{BA} \mathrm{Pb}$ (11581 and 11588), while the $\mathrm{R}_{\mathrm{O}} \%$ polished blocks and slides were stored in GeoLab Sur Laboratory (www.geolab.sur.com).

\section{Provenance and Age}

Squamastrobus tigrensis remains were recovered from the fine-grained, reddish brown siltstone BTO ("Bajo Tigre Otozamites") fossiliferous level in strata belonging to the Anfiteatro de Ticó Formation (Baqueró Group) at the Bajo Tigre locality (Fig. 1). At this level, S. tigrensis is the most abundant plant taxon among the less common Ginkgoites tigrensis
Archangelsky, Mesodescolea plicata Archangelsky, Otozamites ornatus Villar de Seoane, Ruflorinia sierra Archangelsky, Ticoa harrissi Archangelsky, and Ptilophyllum spp. (Archangelsky and Del Fueyo 1987, 1989).

The basal Anfiteatro de Ticó Formation was radiometrically dated as early Aptian, $118.56 \pm 1.4 \mathrm{Ma}$, by Corbella (2001). However, more recently, using the CA-TIMS U-Pb zircon method, Perez Loinaze et al. (2013) estimated a late Aptian age of $118.23 \pm 0.09 \mathrm{Ma}$ for the Anfiteatro de Ticó Formation, whereas Césari et al. (2011) cited an age of $114.67 \pm$ 0.18 Ma for the upper Punta del Barco Formation.

\section{Geological Setting}

The Anfiteatro de Ticó Formation overlies in angular unconformity the Bajo Grande Formation and the Chon Aike Formation, depending on the area (Cladera et al. 2002). This formation represents a floodplain of a network-like riverine ecosystem that periodically received variable amounts of volcanic ash (Archangelsky et al. 1995; Cladera et al. 2002; Archangelsky 2003). According to Cladera et al. (2002), the Anfiteatro de Ticó Formation is composed of siliciclastic and volcaniclastic lithofacies. The former are reddish brown in color and include the following lithofacies: massive $(\mathrm{Gm})$ and through cross-bedded $(\mathrm{Gt})$ clast-supported conglomerates, through cross-bedded coarse-grained sandstones (St), scanty fine-grained sandstones with current ripple cross-lamination $(\mathrm{Sr})$ and dark gray arcilites and limolites, massive (Fm), laminated (Fsc) and with scanty rootlets (Fr). The general cyclicity is well recognized in coarse (Gm-St) and fine (Fm-Fsc, Sr-Fsc-Fm) successions. At Bajo Tigre locality, the volcaniclastic lithofacies are represented by $5 \mathrm{~cm}$ thick layers of fine and whitish tuffs that are massive or badly laminated in gray color interstacked with arcilites and limolites (Cladera et al. 2002).

Following the regional stratigraphic analysis of the Baqueró Group made by Limarino et al. (2012), the BTO fossiliferous level where $S$. tigrensis occurs, is included between the middle and upper sections of depositional sequence 1 and is considered equivalent to stratigraphic levels 4 and 5.

\section{Methods}

Sample Preparations.-Micromorphological and FTIR analyses required different sample preparations. For the former, foliar samples were physically removed from the rock matrix and oxidized in $40 \%$ nitric acid $\left(\mathrm{HNO}_{3}\right)$ for 5-10 minutes, followed by a 5\% ammonium hydroxide $\left(\mathrm{NH}_{4} \mathrm{OH}\right)$ treatment for five minutes, though some cuticles were cleared with $10 \%$ sodium hypochlorite $(\mathrm{NaClO})$ in less than one minute. Foliar cuticles for SEM were mounted on exposed film, glued to stubs and coated with gold-palladium.

For FTIR analyses, each leafy branch was considered to be part of a different plant obtaining nine samples from eight rock samples for which only a mechanical aid was required to remove the relatively loosely attached fossil remains from the sediment. In order to eliminate silicates and other inorganic impurities, samples were treated with $36.5-38.0 \%$ hydrochloric acid $(\mathrm{HCl})$ followed by $70 \%$ hydrofluoric acid $(\mathrm{HF})$, and a final treatment with $36.5-38.0 \% \mathrm{HCl}$. Most of the samples were subdivided into two portions; one portion was retained without further treatment, whereas the other was oxidized in a $50 \% \mathrm{NaClO}$ solution for two minutes to remove mesophyll remnants (Fig. 3). Thus, two samples types were formed: fossilized-cuticle and macerated fossilized-cuticle, respectively, where the latter is hereinafter referred to as cuticle following the terminology outlined in Zodrow et al. (2009). The resulting samples in insufficient amounts for laboratory maceration were only analyzed as fossilized-cuticle specimens, whereas duplicate samples were denoted by "a" and "b" for a total $\mathrm{n}=21$. 


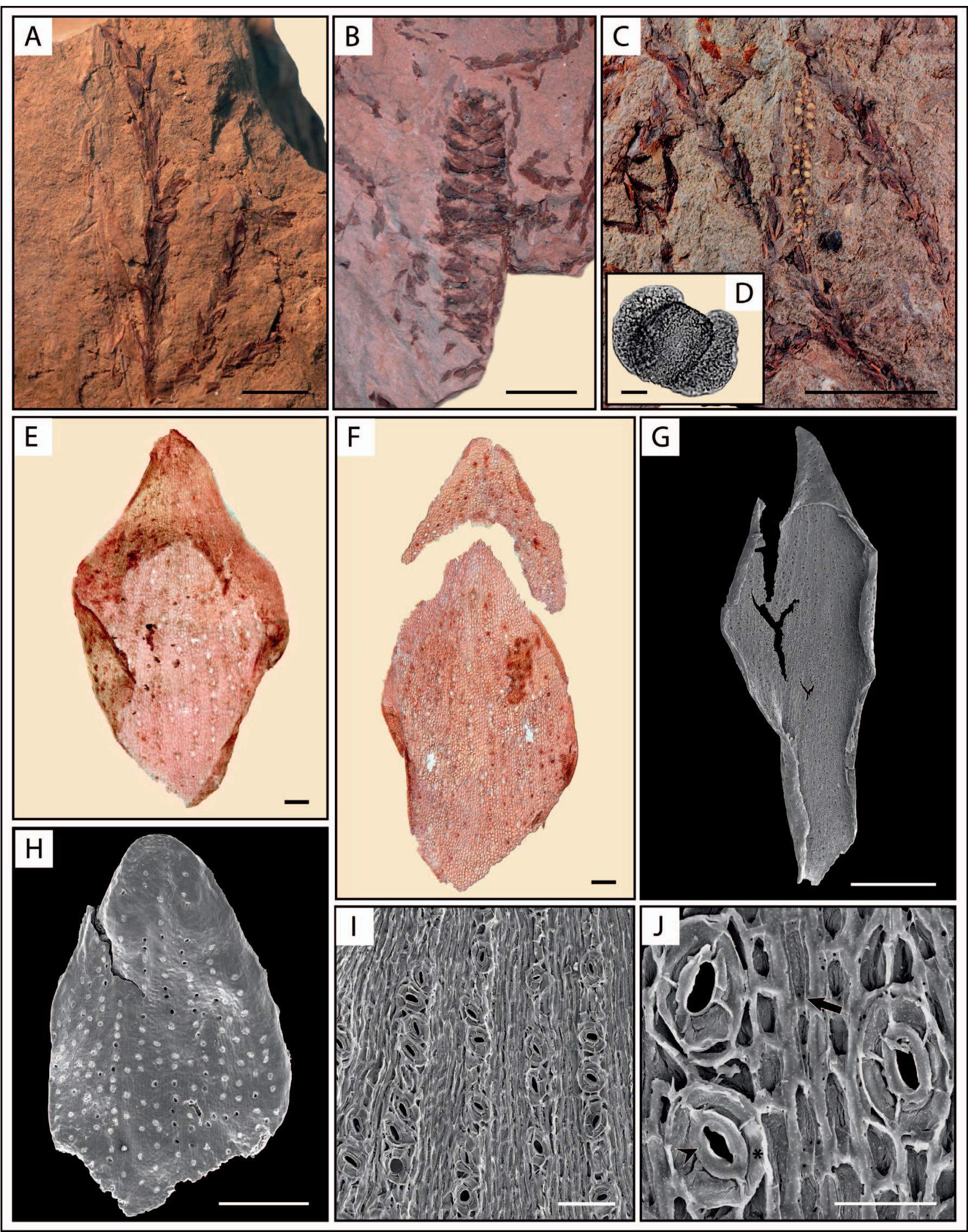

FIg. 2. - Squamastrobus tigrensis Archangelsky and Del Fueyo. A) Vegetative structures. Note scale-like, adpressed leaves helically disposed on branches. Scale $=5$ mm, BA Pb 7681. B) Seed cone. Scale $=1 \mathrm{~cm}, \mathrm{BA} \mathrm{Pb}$ 11341. C) Pollen cone. Scale $=1 \mathrm{~mm}, \mathrm{BA} \mathrm{Pb} 11311$. D) Podocarpidites pollen type, Scale $=10 \mu \mathrm{m}, \mathrm{BA} \mathrm{Pb} 11311$. 


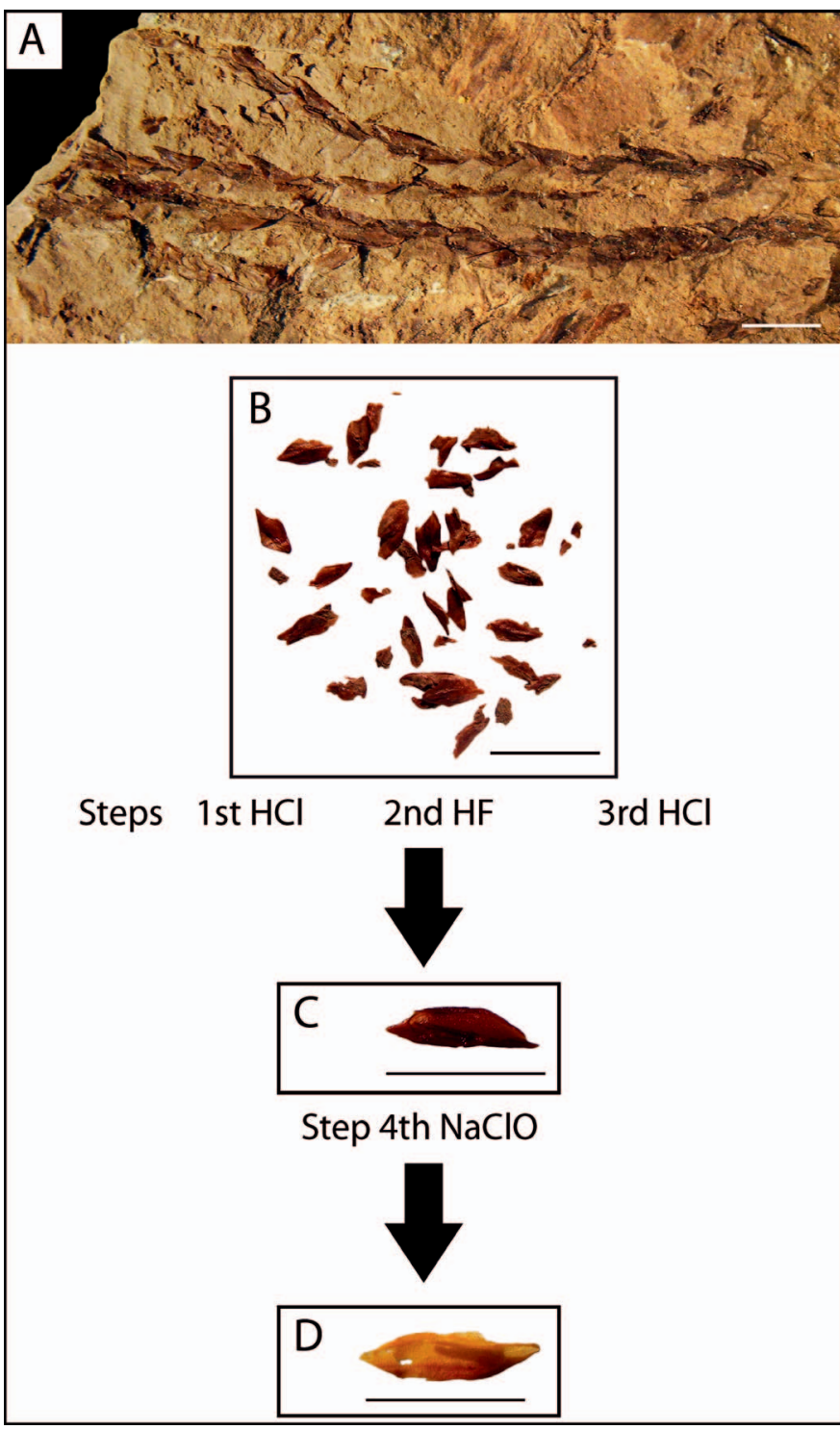

FIg. 3.-Two FTIR sample types: fossilized-cuticles and cuticles. Scales $=5 \mathrm{~mm}$. A) Fossil specimen, BA Pb 12174. B) Foliar compressions released from the rock matrix, BA Pb 11583. C, D) Sample types, BA Pb 11321: (C) Fossilized-cuticle (FC) obtained after steps 1, 2, and 3; (D) Cuticle (Ct) obtained after steps 1, 2, 3, and 4.

Microscopy.—Light-microscopy observations were carried out using a Leitz Diaplan, while micrographs were captured with a Leica DFC 280. SEM was performed on a Philips XL30 SEMTMP $15.1 \mathrm{kV}$ at the Museo Argentino de Ciencias Naturales "Bernardino Rivadavia".

FTIR.-For FTIR analyses, the potassium bromide (KBr) pellet technique (Vidrine 2002) was used, where approximately $2 \mathrm{mg}$ of sample material was mixed with $250 \mathrm{mg} \mathrm{KBr}$, ground and compressed into $13 \mathrm{~mm}$ diameter pellets. These were then analyzed by using a Nicolet ThermoElectron 6700 spectrometer, which accumulated 256 scans at a resolution of $4 \mathrm{~cm}^{-1}$ at wavelengths between $4000 \mathrm{~cm}^{-1}$ and $400 \mathrm{~cm}^{-1}$. Qualitative and semi-quantitative FTIR analyses included assignments of functional groups according to Painter et al. (1981a, 1981b, 1985); Wang and Griffiths (1985); Ganz and Kalkreuth (1987); Colthup et al. (1990); Rochdi and Landais (1991); Guo et al. (1996); Almendros et al. (1999); Shurvell (2002); Stuart (2004); Petersen and Nytoft (2006), Petersen et al. (2008), and D'Angelo and Zodrow (2015). FTIR-band assignments are shown in Table 1. Definitions of the area ratios, together with band regions employed for calculation and interpretation, are summarized in Table 2. Semiquantitative IR information was refined and improved on digitized spectra using well-known techniques for signal processing (e.g., Sobkowiak and Painter 1992; D'Angelo 2004; D'Angelo and Marchevsky 2004). A representative fossilized cuticle sample (FC2) was analyzed using a resolution-enhancement method (REM): subtraction of a multiple $(\times 100)$ of the second derivative from the original spectrum (Rosenfeld and Kak 1982; Almendros and Sanz 1992).

Semi-quantitative measurements of the total contents from selected functional groups were carried out by integrating the total peak area in the following regions: aliphatic $\left(\mathrm{CHal} ; 3000-2800 \mathrm{~cm}^{-1}\right)$, carbonyl $(\mathrm{C}=\mathrm{O}$; $\left.1700-1600 \mathrm{~cm}^{-1}\right)$, aromatic carbon $\left(\mathrm{C}=\mathrm{C} ; 1600-1500 \mathrm{~cm}^{-1}\right)$, and the combined contribution of $\mathrm{C}=\mathrm{O}$ and $\mathrm{C}=\mathrm{C}\left(\mathrm{Ox} ; 1800-1600 \mathrm{~cm}^{-1}\right)$ (e.g., Mastalerz and Bustin 1995; Guo and Bustin 1998; Zodrow and Mastalerz 2007).

Finally, semi-quantitative IR-derived data were organized into a data matrix with nine variables and 21 samples (Table 3 ) that was statistically analyzed.

Multivariate Analysis.-Principal component analysis (PCA) is a nonparametric statistical tool with diverse uses in paleobotany (e.g., Lockheart et al. 2000; DiMichele et al. 2001; D'Angelo and Zodrow 2011, 2015, 2016; Vajda et al. 2017; Zodrow et al. 2017). Its main purpose is to reduce the dimensionality of large data sets while retaining, as much as possible, the variance present in the original data set. This goal is achieved by transforming the original set of variables to a new group of variables, i.e., the principal components (PCs), which are linear combinations of the original variables. PCs are uncorrelated (orthogonal) and are ordered so that the first component has the highest explained variance of all original variables (e.g., Jolliffe 2002; Lattin et al. 2002; Anderson 2003; Izenman 2008).

We retained the number of PCs that explained a cumulative variance of $85.02 \%$ (Kaiser 1960; see Kendall 1965 for other methods). PCA is used to focus on groupings as a function of functional groups (chemical structure) and to evaluate different sample types in terms of FTIR chemical parameters.

Vitrinite Reflectance.-A kerogen concentrate was obtained from the host rock of the BTO fossiliferous level for the determination of organic matter. Samples V1 and V2 were ground into particles smaller than $1 \mathrm{~mm}$ and treated in $10 \% \mathrm{HCl}$ to remove carbonates. Subsequent steps included treatment with $70 \% \mathrm{HF}$, followed by $10 \% \mathrm{HCl}$ rinses. Samples of kerogen concentrate were embedded in epoxy-resin blocks and polished on one side. The $\mathrm{R}_{\mathrm{O}} \%$ values were measured under oil immersion with a Zeiss Axioskop Imager.A2m microscope, a tungsten-halogen lamp (12V, 100W), an Epiplan-Neofluar $50 \times / 1.0$ oil immersion objective, and in incident filtered $(\lambda=546 \mathrm{~nm})$ monochromatic, non-polarized, reflected light.

The microscope is equipped with the TIDAS PMT VI photometer by JandM Analytik AG. Data acquisition was performed according to the ASTM standard technique D7708 (ASTM 2014). Additionally, the polished blocks were observed under epifluorescent light.

E) Entire leaf, BA Pb Pm 655. F) Adaxial epidermis (above) separate from abaxial epidermis (below), BA Pb Pm 648. Scales E, F $=200 \mu$ m. G) General aspect showing adaxial epidermis outer surface and abaxial epidermis inner surface. Scale $=1000 \mu \mathrm{m}, \mathrm{BA} \mathrm{Pb}$ MEB 584 . H) Outer surface of abaxial epidermis. Scale $=500 \mu \mathrm{m}, \mathrm{BA} \mathrm{Pb}$ MEB 580. I) Stomata in abaxial epidermis. Scale $=100 \mu \mathrm{m}, \mathrm{BA}$ Pb MEB 584. J) Subsidiary (*) and guard cells (arrowhead) features. Note remains of hypodermal cells (arrow). Scale $=50 \mu \mathrm{m}$, BA Pb MEB 585 . 
TABLE 1.-Wave number ranges in which main functional groups and classes of compounds absorb.

\begin{tabular}{|c|c|c|}
\hline Range $\left(\mathrm{cm}^{-1}\right)^{\mathrm{a}}$ & Group and class of compound & Assignment \\
\hline $2936-2913$ & Methylene and Methyl $\left(\mathrm{CH}_{3^{-}}, \mathrm{CH}_{2^{-}}\right)$in aliphatic compounds ${ }^{\mathrm{b}}$ & $\mathrm{CH}_{3}-, \mathrm{CH}_{2}-$ antisymmetric stretch \\
\hline $1780-1760$ & $\mathrm{C}=\mathrm{O}$ in $\gamma$-lactones & $\mathrm{C}=\mathrm{O}$ stretch \\
\hline $1750-1730$ & $\mathrm{C}=\mathrm{O}$ in $\delta$-lactones & $\mathrm{C}=\mathrm{O}$ stretch \\
\hline $1740-1720$ & $\mathrm{C}=\mathrm{O}$ in aldehydes & $\mathrm{C}=\mathrm{O}$ stretch \\
\hline $1724-1695$ & Carbonyl $(\mathrm{C}=\mathrm{O})$ in carboxylic acids, ketones & $\mathrm{C}=\mathrm{O}$ stretch \\
\hline $1475-1450$ & $\mathrm{CH}_{2}$ in aliphatic compounds & $\mathrm{CH}_{2}$ bending (scissors) vibration \\
\hline $1465-1440$ & $\mathrm{CH}_{3}$ in aliphatic compounds & Antisymmetric $\mathrm{CH}_{3}$ deformation \\
\hline$\sim 1410$ & $\mathrm{CH}-\left(\mathrm{CH}_{3}\right)$ bond in aliphatic compounds & $\mathrm{CH}-\left(\mathrm{CH}_{3}\right)$ symmetric deformation \\
\hline $1385-1375$ & $\mathrm{CH}_{3}$ in aromatic and aliphatic compounds & $\mathrm{CH}_{3}-\mathrm{Ar}$, R symmetric deformation (e.g. $\mathrm{CH}_{3}$ umbrella deformation) \\
\hline $1240-1070$ & $\mathrm{C}-\mathrm{O}-\mathrm{C}$ in ethers & $\mathrm{C}-\mathrm{O}-\mathrm{C}$ stretch \\
\hline $900-700$ & $=\mathrm{CH}$ in aromatic hydrocarbons & $=\mathrm{C}-\mathrm{H}$ out-of-plane bending \\
\hline
\end{tabular}

${ }^{a}$ According to Painter et al. (1981a, 1981b, 1985); Wang and Griffiths (1985); Ganz and Kalkreuth (1987); Colthup et al. (1990); Rochdi and Landais (1991); Guo et al. (1996); Almendros et al. (1999); Shurvell (2002); Stuart (2004); Petersen and Nytoft (2006); Petersen et al. (2008); D'Angelo and Zodrow (2015).

${ }^{b}$ It should be noted that peak at $2925 \mathrm{~cm}^{-1}$ (obtained after deconvolution of aliphatic $\mathrm{C}-\mathrm{H}$ stretching region, not shown) represents the contribution from $\mathrm{CH}_{3}$ and $\mathrm{CH}_{2}$ groups attached directly to aromatic rings (see Petersen and Nytoft 2006).

TABLE 2.-Definition of semi-quantitative ratios derived from FTIR spectra.

\begin{tabular}{lcc}
\hline \hline Ratio & Band-region $\left(\mathrm{cm}^{-1}\right)$ \\
& BCA variable & Inderpretation and remarks
\end{tabular}

$\mathrm{CH}_{2} / \mathrm{CH}_{3} \quad 3000-2800$

$\mathrm{CHal} / \mathrm{Ox}$

$(3000-2800) /(1800-1600)$

$\begin{array}{ll}\mathrm{C}=\mathrm{O} / \mathrm{C}=\mathrm{C} & (1700-1600) /(1600-1500) \\ \mathrm{C}=\mathrm{O} \text { cont } & (\sim 1714) /(1800-1600) \\ \mathrm{C}=\mathrm{C} \text { cont } & (\sim 1600) /(1800-1600) \\ \mathrm{CHal} / \mathrm{C}=\mathrm{C} & (3000-2800) /(1600-1500)\end{array}$

'A' Factor $=\mathrm{CHal} /(\mathrm{CHal}+\mathrm{C}=\mathrm{C}) \quad(3000-2800) /[(3000-2800)+(1600-1500)]$

${ }^{\mathrm{C}} \mathrm{C}$. Factor $=\mathrm{Ox} /(\mathrm{Ox}+\mathrm{C}=\mathrm{C}) \quad(1800-1600) /[(1800-1600)+(1600-1500)]$

$\mathrm{CHal} / \mathrm{C}=\mathrm{O}$

$(3000-2800) /(1800-1700)$
Methylene/methyl ratio. It relates to aliphatic chain length and degree of branching of aliphatic side groups (side chains attached to macromolecular structure; Lin and Ritz 1993a, 1993b). Higher value implies comparatively longer and straight chains, a lower value shorter and more branched chains. Caution is advised using the ratio, as it may be misleading due to the contribution from $\mathrm{CH}_{2}$ and $\mathrm{CH}_{3}$ groups attached directly to aromatic rings (Petersen and Nytoft 2006).

Aliphatic/oxygen-containing compounds ratio. Relative contribution of aliphatic $\mathrm{CH}$ stretching bands (CHal) to the combined contribution of oxygen-containing groups and aromatic carbon (Ox). From higher values decreasing oxygen containing groups can be inferred, or the lower the $\mathrm{CHal} / \mathrm{Ox}$ ratio, the higher the $\mathrm{Ox}$ term. This ratio could provide some information about oxidation in organic matter (e.g., Mastalerz and Bustin 1997; Zodrow and Mastalerz 2001).

Carbonyl/aromatic ratio of carbon groups. Relative contribution of $\mathrm{C}=\mathrm{O}$ to aromatic carbon groups. Higher values indicate increasing carbonyl/carboxyl groups to aromatic carbon groups (D'Angelo 2006).

Carbonyl contribution. Relative contribution of carbonyl/carboxyl groups $(\mathrm{C}=\mathrm{O}$; peak centered near $1714 \mathrm{~cm}^{-1}$ ) to combined contribution of oxygen-containing groups and aromatic carbon $(\mathrm{C}=\mathrm{C})$ structures.

Aromatic carbon contribution. Relative contribution of aromatic carbon groups $(\mathrm{C}=\mathrm{C}$; peak in 1650 to $1520 \mathrm{~cm}^{-1}$ region, centered near $1600 \mathrm{~cm}^{-1}$ ) to combined contribution of oxygen-containing groups and aromatic carbon $(\mathrm{C}=\mathrm{C})$ structures.

Aliphatic/aromatic carbon groups ratio. Relative contribution of aliphatic $\mathrm{C}-\mathrm{H}$ stretching bands to aromatic carbon groups $(\mathrm{C}=\mathrm{C})$. Higher values indicate increasing aliphatic groups to aromatic carbon groups. This ratio is equivalent to the I1 index of Guo and Bustin (1998).

A Factor. Relative contribution of aliphatic $\mathrm{C}-\mathrm{H}$ stretching bands to sum of aliphatic $\mathrm{C}-\mathrm{H}$ stretching and aromatic carbon structures. According to Ganz and Kalkreuth (1987) it represents change in relative intensity of aliphatic groups.

$\underline{C}$ Factor. Relative contribution of oxygen containing compounds to sum of oxygen containing structures and aromatic carbon bands. According to Ganz and Kalkreuth (1987) it represents change in carbonyl/carboxyl groups.

Aliphatic/carbonyl groups ratio. Relative contribution of aliphatic C-H stretching bands to carbonyl/carboxyl groups $(\mathrm{C}=\mathrm{O})$. Indicator for cross-linking degree of a polymeric structure (i.e., the linking of polymer chains). Lower values indicate higher $\mathrm{C}=\mathrm{O}$ content and higher cross-linking (Benítez et al. 2004). 
TABLE 3.-Complete data set of semi-quantitative FTIR data relating to Squamastrobus tigrensis samples from Anfiteatro de Ticó Formation.

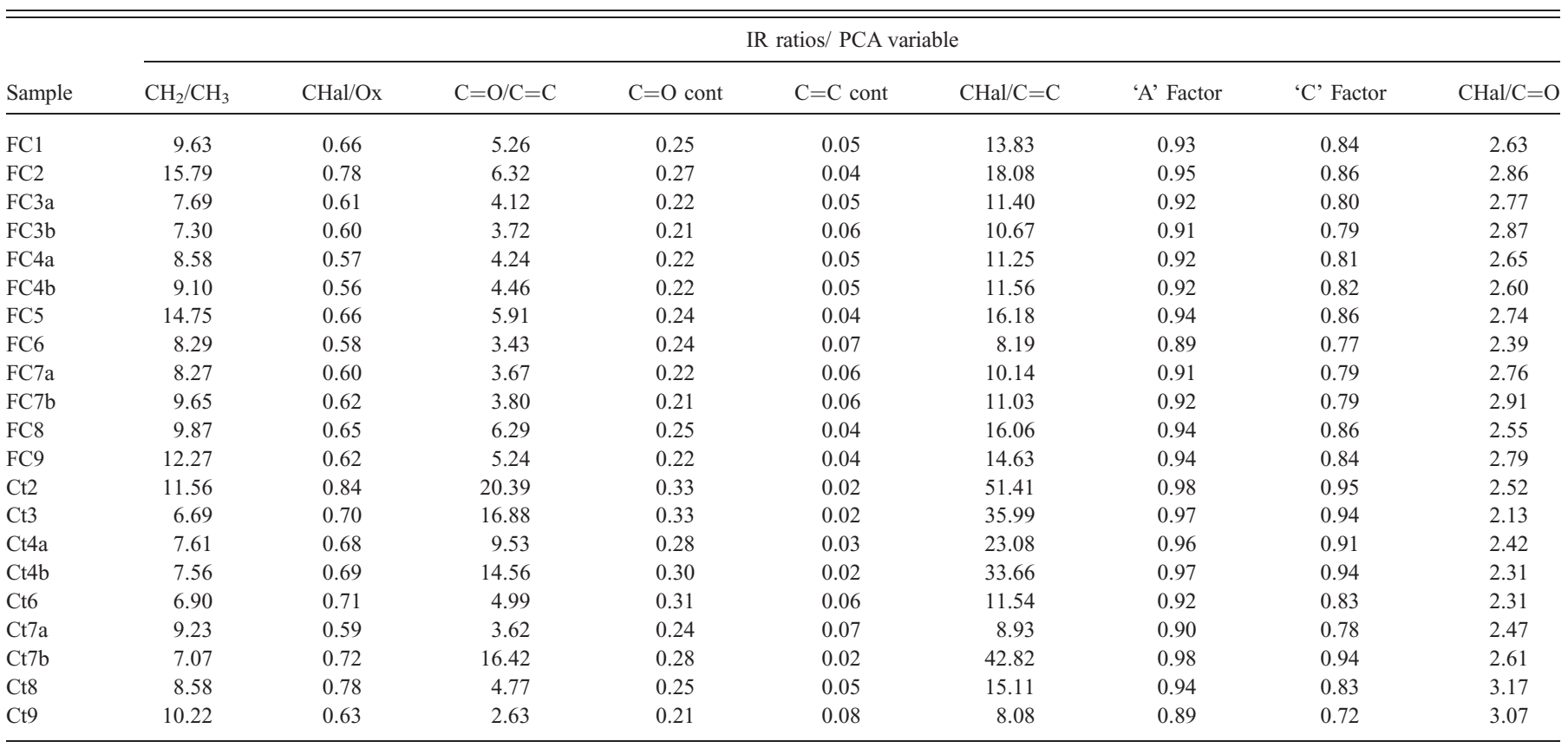

In addition to the specific $\mathrm{R}_{\mathrm{O}} \%$ value, were estimated percentages of amorphous material and of the following maceral groups: liptinite (ICCP 1971, 1975; Stach et al. 1982; Teichmüller 1989; Taylor et al. 1998), inertinite (Taylor et al. 1998; ICCP 2001) and vitrinite (ICCP 1998; Sýkorová et al. 2005). V1 and V2 samples were mounted in glycerin jelly and observed with a Zeiss Axioskop Imager.A2m microscope under transmitted light and epifluorescence. Thus, together with the reflected light and epifluorescence-microscopy information from the polished blocks, organoclasts and minerals were identified.

Complementary to $\mathrm{R}_{\mathrm{O}} \%$, other thermal maturity indicators were measured according to the data-acquisition procedures of GeoLab Sur Laboratory, thermal alteration index (TAI) and vitrinite reflectance equivalent (VRE). Thermal maturity indices were employed as an approximation to the transformation processes that occurred at the BTO fossiliferous level.

\section{RESULTS}

\section{Host Rock: Maceral Groups and $R_{O} \%$ Data}

Characterization of dispersed organic matter in V1 and V2 samples (Table 4) was based on (1) organic constituents, i.e., macerals, macerals groups, and amorphous organic matter (AOM, Tyson 1995); (2) mineral content; and (3) thermal maturity indices of the organic components.
$\mathrm{AOM}$ is the most abundant fraction at $75-80 \mathrm{wt} \%$ (Table 4), characterizing non-coaly organic rocks (Suárez-Ruiz et al. 2012). At low thermal maturity, AOM, as well as the liptinite maceral group (Fig. 4E, 4F), are typically fluorescent. The most common maceral group is liptinite, whereas only traces of inertinite were detected (Table 4). The vitrinite group is present in limited amounts at 5\% (Table 4, Fig. 4A, 4B). Organoclasts are recognized by the presence of cuticles (cutinite), and pollen grains and spores (sporinite) (Fig. 4C, 4D). The spores are translucent and well-preserved. Additionally, unidentified liptinite fragments (liptodetrinite) are recorded.

Mineral content is represented by fine-grained, granular, and framboid pyrite (Fig. 4A, 4B, Table 4), which showed high reflectance and poorly defined contours.

$\mathrm{R}_{\mathrm{O}} \%$ values of 0.45 and 0.49 are recorded at the BTO fossiliferous level (Table 4), and the TAI value of $2 / 2+$ is correlated to a VRE $\%$ of 0.40 (Table $4)$; or essentially the additional maturity indices are in agreement with the $\mathrm{R}_{\mathrm{O}} \%$ values. The values of thermal- maturity indices indicate relatively immature sediments.

\section{Qualitative Chemical Characterization: FTIR Spectra of Fossilized- Cuticles and Cuticles}

Representative IR-spectra of the two sample types are shown (Fig. 5). Irrespective of the sample types, FTIR spectra exhibited common

TABLE 4.- Host rock samples obtained from two fossil specimens (i.e., BA Pb 11581 and 11588) belonging to the BTO fossiliferous level. Abbreviations: $R o \%=$ vitrinite reflectance; $T A I=$ thermal alteration index; VRE = vitrinite reflectance equivalent; Fluor. $=$ fluorescent; Non-fluor. $=$ non-fluorescent;

$$
\operatorname{Tr}=\text { traces (lower than 5\%); Spor. = sporinite; Cut. = cutinite; Liptdr. = Liptodetrinite. }
$$

\begin{tabular}{|c|c|c|c|c|c|c|c|c|c|c|c|c|}
\hline Sample & \multicolumn{4}{|c|}{ Maturity } & \multicolumn{2}{|c|}{ Amorphous\% } & \multicolumn{3}{|c|}{ Liptinite group $\%$} & $\begin{array}{l}\text { Vitrinite } \\
\text { group (\%) }\end{array}$ & $\begin{array}{l}\text { Inertinite } \\
\text { group (\%) }\end{array}$ & Pyrite \\
\hline V1 & $0.45 \pm 0.07$ & 26 & $2 / 2+$ & 0.4 & 80 & - & 15 & $\operatorname{Tr}$ & $\operatorname{Tr}$ & 5 & $\operatorname{Tr}$ & Finely granular and framboidal \\
\hline
\end{tabular}




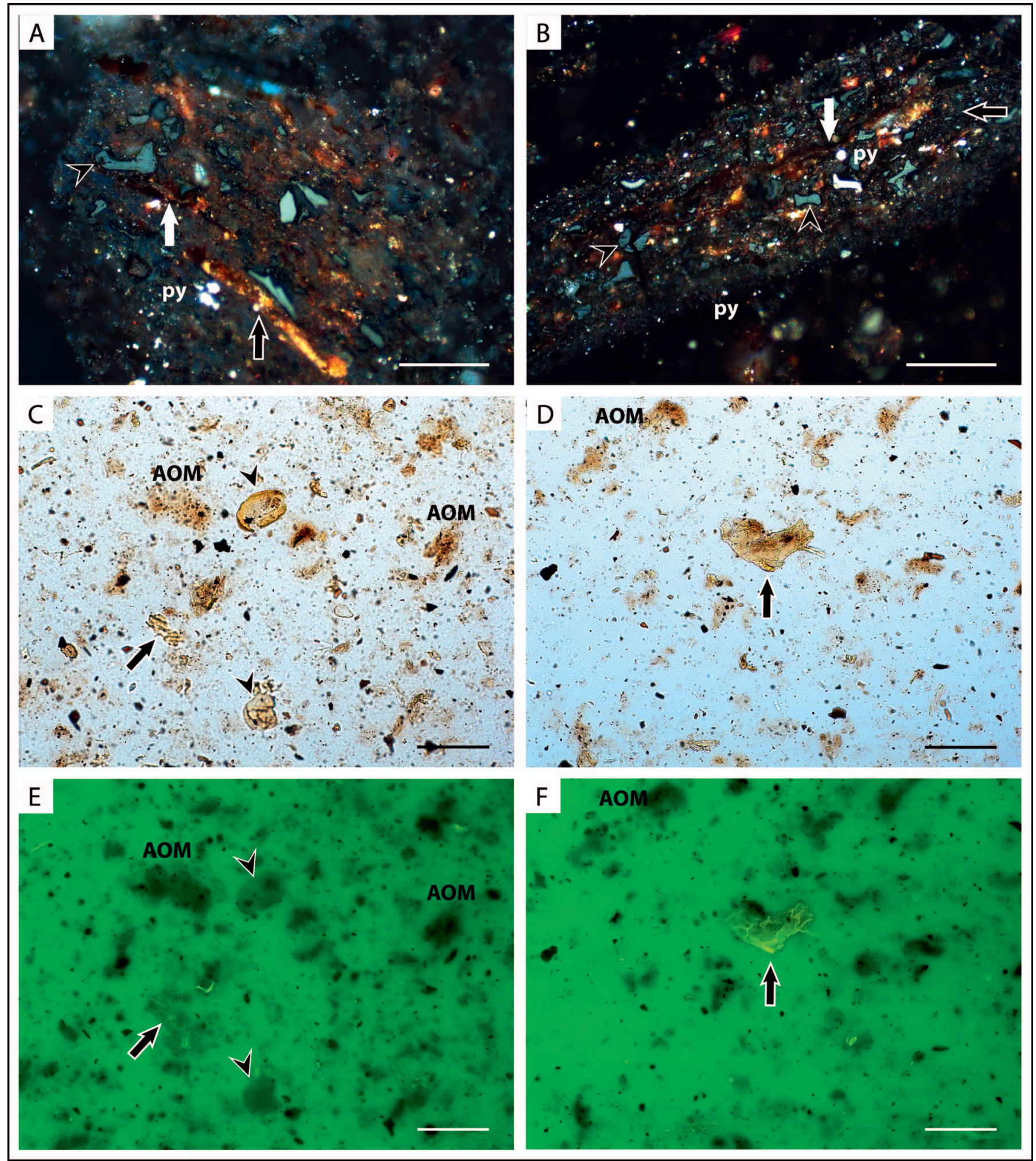

FIG. 4. - Kerogen concentrate obtained from the host rock samples (BTO fossiliferous level): V1 (photos on the left) and V2 (photos on the right). A, B) Polished block surface. Reflected light. Liptinite group maceral represented by reddish orange to golden yellow zones within the diffuse amorphous material (black arrow) and by dark laminate structure (white arrow) probably assignable to an organic membrane of an uncertain structure wall. Dispersed pyrite (py) of variable size and form (granular to framboidal) showing the highest reflectance. Arrowhead indicates vitrinite. Scale $=100 \mu \mathrm{m}$. C-F) Pollen grains (arrowhead), cuticle remains (arrow), amorphous organic matter (AOM). Scales $=200 \mu \mathrm{m}$. Notes: (C, D) under transmitted light and (E, F) under epifluoresecence; fragments that conform to the liptinite group (pollen grains and cuticles) show variable fluorescence. 


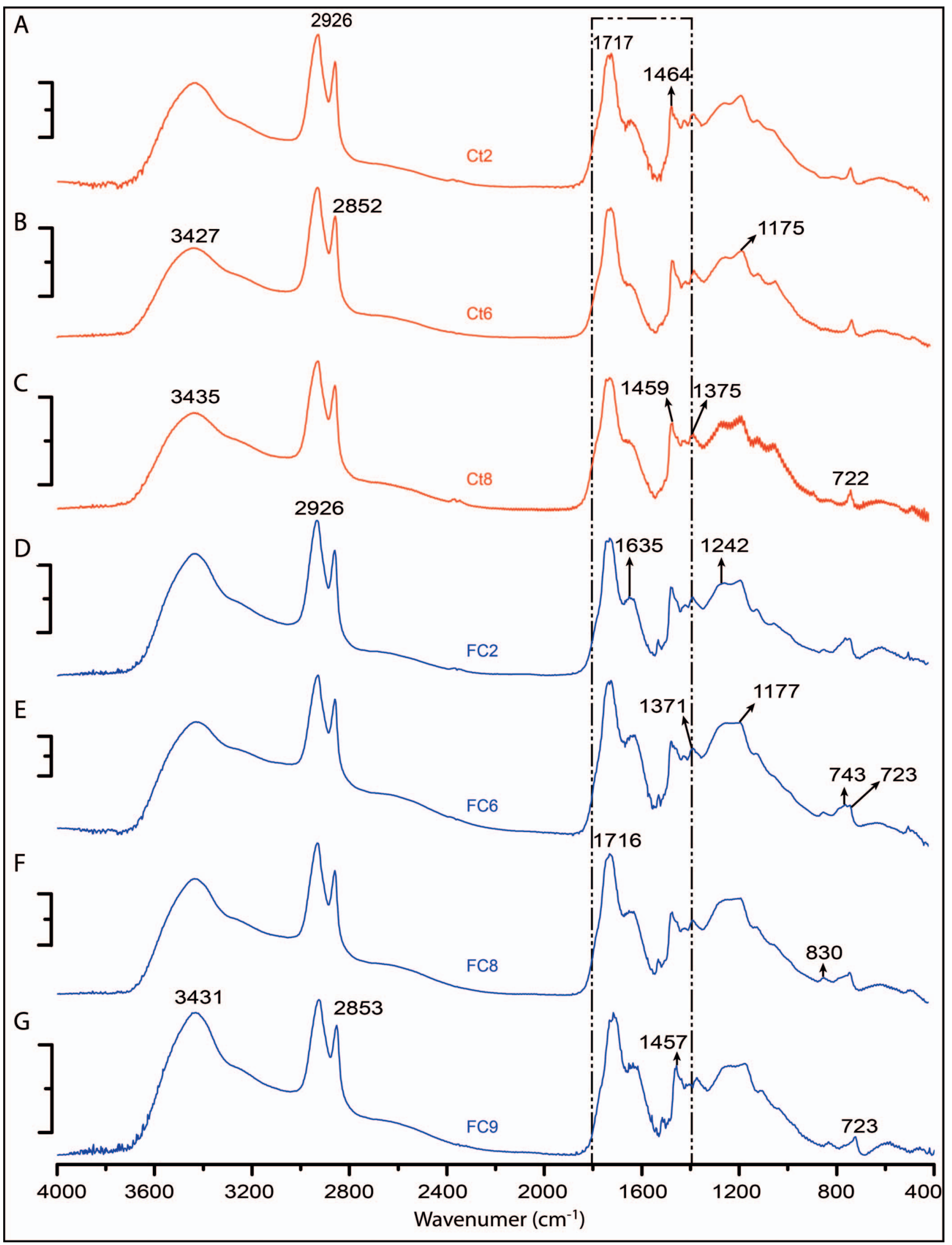

FIG. 5.-Representative FTIR spectra. A-C) Cuticles $=$ Ct. D-G) Fossilized-cuticles $=$ FC. Note absorbance in y-axis and distinctive spectral region $\left(1800-1000 \mathrm{~cm}^{-1}\right)$ 


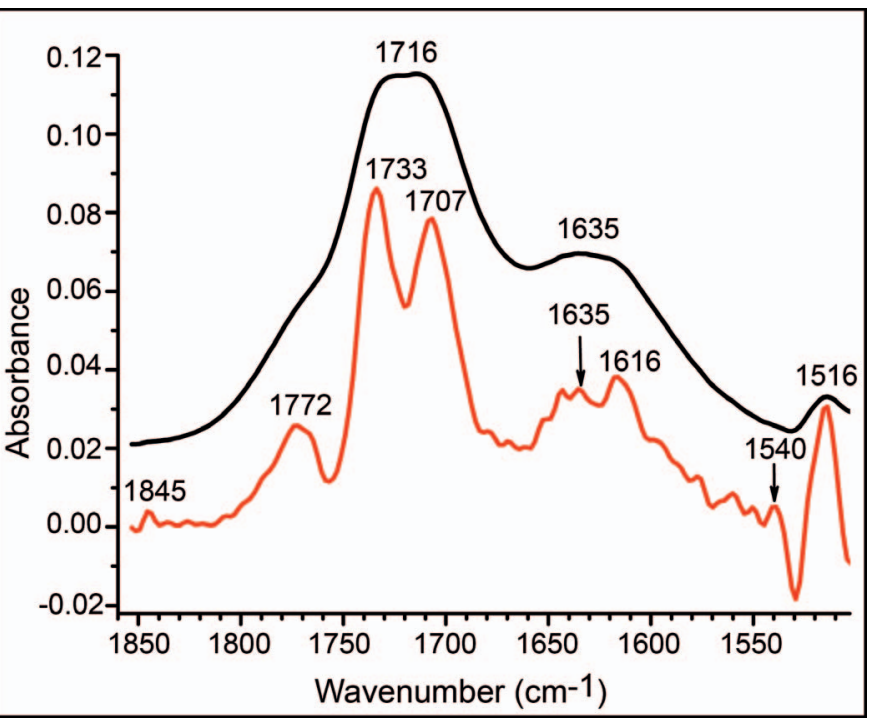

FIG. 6.- Representative FTIR spectra of FC2 sample using the resolution enhancement method (REM).

functional groups, summarized as follows. A broad, intense, and ubiquitous band centered between $3446-3419 \mathrm{~cm}^{-1}$ is attributed to hydroxyl $(\mathrm{OH})$ stretch in alcohols and phenols. Different peaks assigned to aliphatic C-H stretching vibrations in the $3000-2600 \mathrm{~cm}^{-1}$ region are present in both cuticles and fossilized-cuticles and are assigned to the antisymmetric methylene $\left(\mathrm{CH}_{2}\right)$ stretch $\left(2926-2922 \mathrm{~cm}^{-1}\right)$ and symmetric $\mathrm{CH}_{2}$ stretch $\left(\sim 2853 \mathrm{~cm}^{-1}\right)$. Methyl $\left(\mathrm{CH}_{3}\right)$ peaks are detected after the application of the Fourier self-deconvolution technique (Lin and Ritz 1993a, 1993b).

Carboxyl $(\mathrm{COOH})$ and other carbonyl $(\mathrm{C}=\mathrm{O})$ groups (e.g., ketones) absorbed in the 1740-1700 $\mathrm{cm}^{-1}$ region (Rochdi and Landais 1991; Guo et al. 1996). Fossilized cuticles and cuticles show $\mathrm{C}=\mathrm{O}$ peaks of middle to high intensities, with an absorption maximum at $1716 \mathrm{~cm}^{-1}$, which are assigned to aromatic carbonyl groups.

Middle intensity bands assigned to aliphatic C-H deformations (alkyl C$\mathrm{H}$ bending mode) are present in the spectra of fossilized-cuticles and cuticles. These bands occur at $1464-1458 \mathrm{~cm}^{-1}$ and represent $\mathrm{CH}_{2}$ scissor deformations or asymmetric methyl $\left(\mathrm{CH}_{3}\right)$ deformations (see Gauglitz and Vo-Dinh 2003 for definitions of the $\mathrm{CH}_{2}$ and $\mathrm{CH}_{3}$ vibrational groups). Medium-to-low intensity peaks at $1375-1373 \mathrm{~cm}^{-1}$ could be attributed to $\mathrm{CH}_{3}$ umbrella deformations, though the contribution of SI-O stretch in silicates (mineral impurities) is not ruled out.

In all samples, a shoulder recorded at $\approx 1260-1235 \mathrm{~cm}^{-1}$ could be assigned to ether bonds (C-O-C bond). A low-to-middle intensity band at $1190-1172 \mathrm{~cm}^{-1}$ represents symmetric C-O-C vibrations.

Some low intensity bands, related to $=\mathrm{CH}$ bond, are usually present at $900-700 \mathrm{~cm}^{-1}$ region. In fossilized-cuticle spectra, a band at $\approx 830 \mathrm{~cm}^{-1}$ corresponds to the aromatic C-H out-of-plane bending. Cuticles rarely show aromatic bands in this region, and $S$. tigrensis is not an exception. Bands at $725-722 \mathrm{~cm}^{-1}$ and at $743-723 \mathrm{~cm}^{-1}$ represent $\mathrm{CH}_{2}$ rocking vibrations in cuticles and fossilized-cuticles, respectively.

The application of the resolution-enhancement method (REM) revealed new peaks, where only shoulders were recognized in the original spectrum. A representative sample (i.e., FC2) is shown in Figure 6. The main peaks shown by all studied samples in the spectral zone $1850-1500 \mathrm{~cm}^{-1}$ included $1716 \mathrm{~cm}^{-1}, 1635 \mathrm{~cm}^{-1}$ (assigned to $\mathrm{C}=\mathrm{O}$ stretch), and $1516 \mathrm{~cm}^{-1}$ $(\mathrm{C}=\mathrm{C}$ ring stretching). After the application of REM, new peaks were revealed at $1772 \mathrm{~cm}^{-1}, 1733 \mathrm{~cm}^{-1}$, and $1707 \mathrm{~cm}^{-1}$, which are attributable to $\mathrm{C}=\mathrm{O}$ stretch in $\gamma$-lactones, aldehydes and ketones, respectively. New peaks recorded at $1635 \mathrm{~cm}^{-1}, 1616 \mathrm{~cm}^{-1}, 1540 \mathrm{~cm}^{-1}$, and $1516 \mathrm{~cm}^{-1}$ are assigned to $\mathrm{C}=\mathrm{C}$ ring stretching.

\section{Semi-Quantitative Approach}

PCA.-Cumulatively, two PCs account for $85.02 \%$ of the cumulative variance (see Online Supplemental file). Plots of component loadings and component scores are provided (Fig. 7A, 7B). PC 1 (68.35\% explained variance) has positive loadings on $\mathrm{C}=\mathrm{C}$ cont, and negative loadings on the 'A' Factor, ' $\mathrm{C}$ ' Factor, $\mathrm{C}=\mathrm{O} / \mathrm{C}=\mathrm{C}, \mathrm{C}=\mathrm{O}$ cont, $\mathrm{CHal} / \mathrm{Ox}$, and $\mathrm{CHal} / \mathrm{C}=\mathrm{C}(\mathrm{x}-$ axis, Fig. 7A). This pattern reflects the presence of aromatic-carbon functional groups versus aliphatic- and oxygen-containing functionalities.

Two cuticular samples, $\mathrm{Ct} 7 \mathrm{a}$ and $\mathrm{Ct} 9$, as well as most of the fossilizedcuticle specimens including FC3a, FC3b, FC4a, FC4b, FC6, FC7a, and FC7b, showed the most positive scores against PC 1 (x-axis, Fig. 7B), reflecting their high content of aromatic functional groups. This result is confirmed by (1) the highest values of aromatic-related functionalities
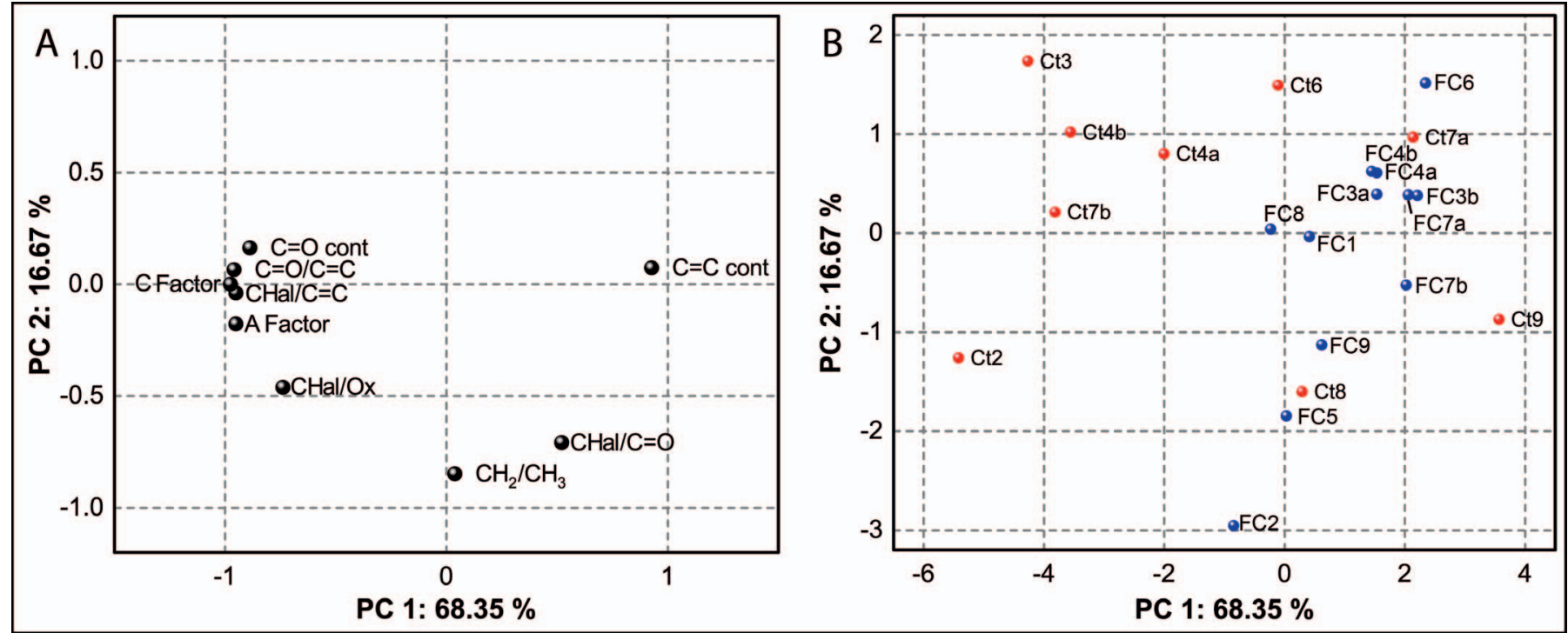

FIG. 7.-PCA (principal component analysis). A) Plot of PC 1 versus PC 2 component loadings. B) Plot of PC 1 versus PC 2 component scores. 
determined and (2) the lowest values of aliphatic- and oxygen-containing functional groups (Table 3).

Higher values of $\mathrm{C}=\mathrm{C}$ cont recorded for fossilized-cuticle samples are likely the result of mesophyll-derived organic compounds preserved between epidermises. FC6 has the highest value $(0.07)$ of $\mathrm{C}=\mathrm{C}$ cont and is the relatively most coalified sample.

Most cuticles have negative scores against the first component reflecting their aliphatic nature and the content of oxygen-bearing functional groups. Some cuticles (Ct7a, Ct8, and $\mathrm{Ct} 9$ ) have positive scores against PC 1. When compared to other cuticular samples, $\mathrm{Ct} 8$ and $\mathrm{Ct} 9$ have the highest values of $\mathrm{CHal} / \mathrm{C}=\mathrm{O}$ (3.17 and 3.07 , respectively), indicating the lowest amount of carbonyl groups. This dynamic could be the result of the rupture of ester bonds, implying a lower cross-linking degree of cuticular polymeric structures (e.g., cutin, cutan). On the other hand, Ct7a has positive scores against $\mathrm{PC} 1$ as shown by its $\mathrm{C}=\mathrm{C}$ cont ratio (0.07), which is the highest value of the entire cuticle data set.

PC 2 (16.67\% of explained variance) shows negative loadings on $\mathrm{CH}_{2}$ $\mathrm{CH}_{3}, \mathrm{CHal} / \mathrm{C}=\mathrm{O}$, and $\mathrm{CHal} / \mathrm{Ox}$ (y-axis, Fig. 7A). This component reflects the abundance of aliphatic groups having long and unbranched polymethylenic chains.

Scores against PC 2, shown by fossilized-cuticle samples, vary from high negative values to high positive (y-axis, Fig. 7B), and similar trends are exhibited by cuticles. These findings show the variability in the aliphatic composition within each group of fossilized-cuticle and cuticle.

FC2 has the most negative scores against PC 2 because of the higher values for $\mathrm{CH}_{2} / \mathrm{CH}_{3}$, ' $\mathrm{A}$ ' and ' $\mathrm{C}$ ' factors, and the relatively lower value of $\mathrm{C}=\mathrm{C}$ cont recorded for this sample. Samples FC5, FC7b, and FC9 also have negative scores against PC 2. The latter indicates the abundance of aliphatic compounds with relatively shorter and more branched polymethylenic side chains, as well as a comparatively high cross-linking degree of polymeric structure (low values of $\mathrm{CHal} / \mathrm{C}=\mathrm{O}$ ).

Squamastrobus tigrensis Remains and Their Relation to Kerogen Types and Coal Macerals. - Some semi-quantitative IR-derived data (Table 3) are used in this section to address maturity and similarity with coal macerals and kerogen types in an attempt to characterize differences in functional groups within fossil preservation types found in $S$. tigrensis.

Thus, IR functional-group ratios from the two sample types are compared with some of the few available coal-maceral IR data from the literature. In this way, some IR data for liptinite, vitrinite, and inertinite (Mastalerz and Bustin 1996; Guo and Bustin 1998) with approximately the same rank $\left(\mathrm{R}_{\mathrm{O}} \max 0.52 \%-1.41 \%\right)$ are compared with $S$. tigrensis IR data. 'A' versus 'C' factor plots (as defined by Ganz and Kalkreuth 1987; see Guo and Bustin 1998) show all the sample types, similarly to the traditional van Krevelen $\mathrm{H} / \mathrm{C}-\mathrm{O} / \mathrm{C}$ plot, indicating similarities with different types of kerogen (Fig. 8A). It should be noted that the boundaries between kerogen types are only approximate, and IR peak area (not intensity) was used to calculate ' $\mathrm{A}$ ' and ' $\mathrm{C}$ ' factors. Figure $8 \mathrm{~B}$ is a simplified plot of Figure 8A, indicating the approximate regions of different sample types (ellipses around the groups do not have statistical significance).

Values of 'A' and 'C' factors obtained for $S$. tigrensis fossilized-cuticle samples were very high, similar to the values obtained for their cuticles and similar to those of some alginite and bituminite samples (Fig. 8A, 8B). These findings indicate a general chemical composition similar to that of type I/ II kerogen, which is characterized by a higher content of both aliphatic groups ('A' Factor) and oxygen-containing compounds (' $\mathrm{C}$ ' Factor). This dynamic is explained by the rich aliphatic character of cuticles, where higher contents of $\mathrm{C}=\mathrm{O}$ groups indicate a high degree of cross linking among polymethylenic chains. This explanation is in agreement with some published IR-derived data (D'Angelo et al. 2010; D'Angelo and Zodrow 2011; Zodrow et al. 2016).

\section{DISCUSSION}

\section{Thermal Maturity Evaluation}

Paleoenvironmental studies of the studied deposits indicate a continental setting (Cladera et al. 2002; Limarino et al. 2012), implying that maceral groups are related to the terrestrial input of plant materials that contribute to organic matter accumulation. We consider that inertinite and vitrinite were derived mostly from higher plant tissues. The low contents of inertinite and vitrinite could be an indication of the limited input of parenchymatous and woody tissues (lignin and cellulose), or the low preservation of higher plants as dispersed organic matter. In fact, S. tigrensis and other plant fossil remains previously reported for the BTO fossiliferous level do not include woody material, which is the most important lignin source. Thus, vitrinite and inertinite could be related mainly to cellulose transformation (in particular conditions avoiding the decay) and, to a lesser extent, lignified-mesophyll material transformation.

The high content of amorphous organic matter is related to terrestrial plant organic matter that has undergone a microbiological reworking in reducing conditions, where the plant material was reworked by heterotrophic bacteria (Mendonça Filho et al. 2012). In turn, the formation and preservation of amorphous organic matter reveals specific conditions at the BTO fossiliferous level, such as organic matter degradation under a combination of aerobic and anaerobic conditions (Suárez-Ruiz et al. 2012).

$\mathrm{R}_{\mathrm{O}} \%$ is commonly used to assess the thermal maturity of dispersed organic matter, considering physical aspects of heat parameters, and hence, diagenetic influence on the biomacromolecules. Our host rock evaluation through thermal maturity indices $\left(\mathrm{R}_{\mathrm{O}} \%\right.$, TAI, and VRE, Table 4) indicates immature sediments that are correlated mainly to temperatures below $50^{\circ} \mathrm{C}$ and approximately indicating the limit of diagenesis-catagenesis (Hunt 1996; Hunt et al. 2002; Peters et al. 2005; Tissot and Welte 1984).

Under such circumstances, one of the main agents of transformation is microbial activity (biological alterations), and subsequent chemical and physical alterations of organic matter (Tissot and Welte 1984). In addition, low $\mathrm{R}_{\mathrm{O}} \%$ values indicate that favorable conditions prevailed for the preservation of coalified S. tigrensis remains. The latter implies a maximum carbon content of $88 \%$ (Larsen 1988). In fact, higher carbon concentrations (low volatile contents) would give rise to the formation of tighter molecular carbon cross-linking, thus precluding an adequate preservation of fossil compressions and the loss of valuable chemical information. Similarly, on a dry-ash basis, Barthel (1962) estimated a maximum value of $72 \%$ carbon content (or a minimum value of $28 \%$ volatiles) for the preservation of cuticles in compressions (see also Zodrow et al. 2009).

Overall, our results indicate that the $S$. tigrensis remains and the entombing sediments were likely exposed only to diagenetic processes at the BTO fossiliferous level. Here, the original organic matter was preferentially transformed into a liptinite maceral by a variety of unknown geochemical reactions that occurred during burial and diagenesis. Fossilized-cuticles of $S$. tigrensis are described by a simplified model involving the likely mesophyllous transformation into cutinite:

$$
\begin{aligned}
\text { Fossilized-cuticle }= & \text { cutinite }(\text { mesophyll }) \\
& + \text { cuticle }(\text { cutinite-like biomacropolymer }) .
\end{aligned}
$$

\section{Squamastrobus tigrensis Preservation}

Plant-organ preservation is controlled by variable physicogeochemical conditions proceeding along a multidimensional continuum and resulting in different preservation types (e.g., Bomfleur et al. 2014; Gupta et al. 2007a, 2007b; Zodrow and Mastalerz 2001, 2002; Zodrow et al. 2009, 2012; D'Angelo et al. 2012). Accordingly, three general states of plant fossil preservation were defined: compressions, fossilized-cuticles, and cuticle-free coalified layers (Zodrow and Mastalerz 2001, 2009; Zodrow et al. 2009). 


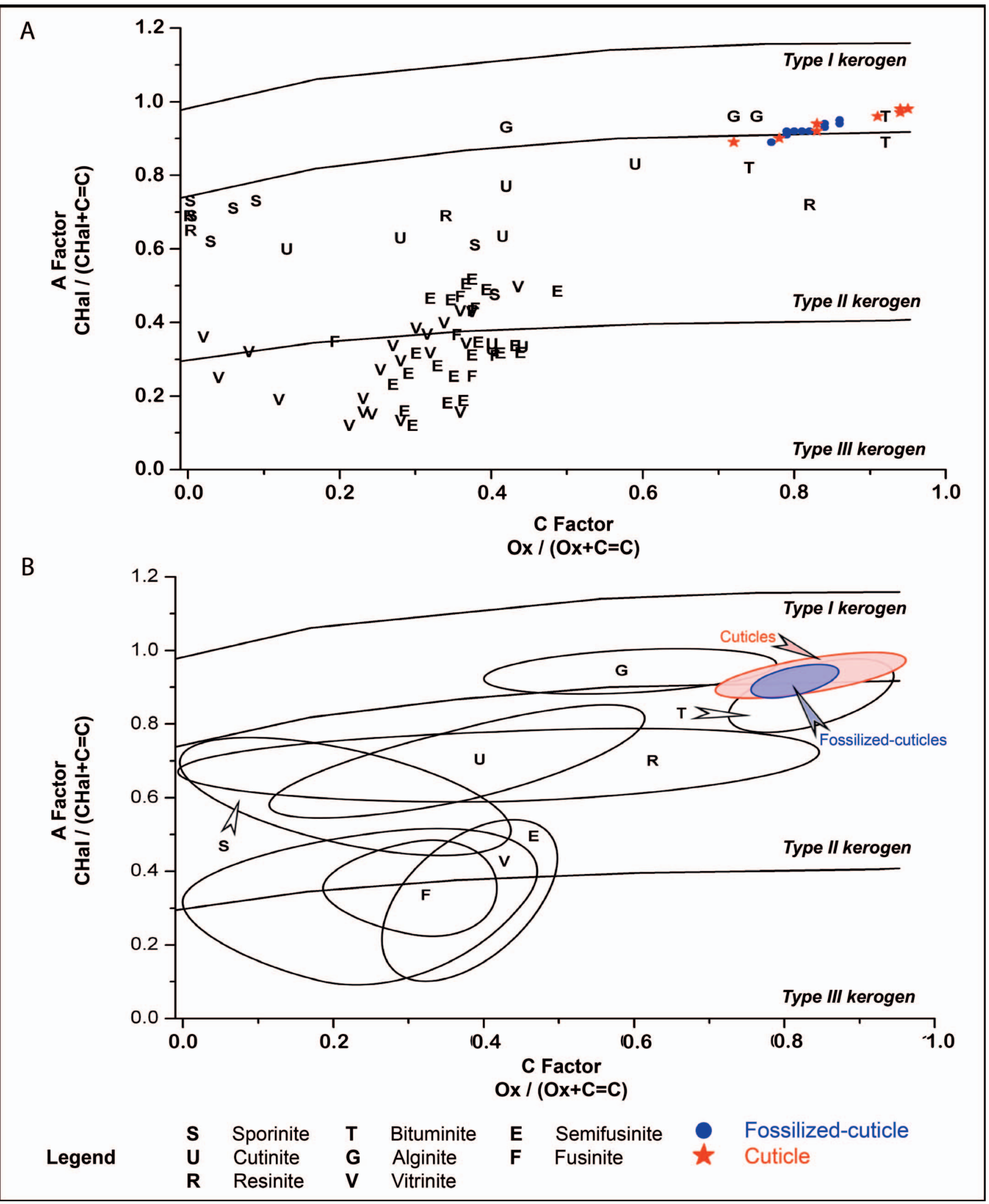

FIG. 8. - Squamastrobus tigrensis fossilized-cuticles and cuticles IR data plotted into the Kerogen-type diagram. A) Full-scale diagram. Sources of coal maceral data are: Mastalerz and Bustin (1996; sporinite, cutinite, vitrinite, semifusinite, and fusinite), and Guo and Bustin (1998; cutinite, resinite, bituminite, alginite, and vitrinite). B) Simplified plot of (A) indicating approximate regions for different sample types (ellipses around the groups have no statistical significance). 


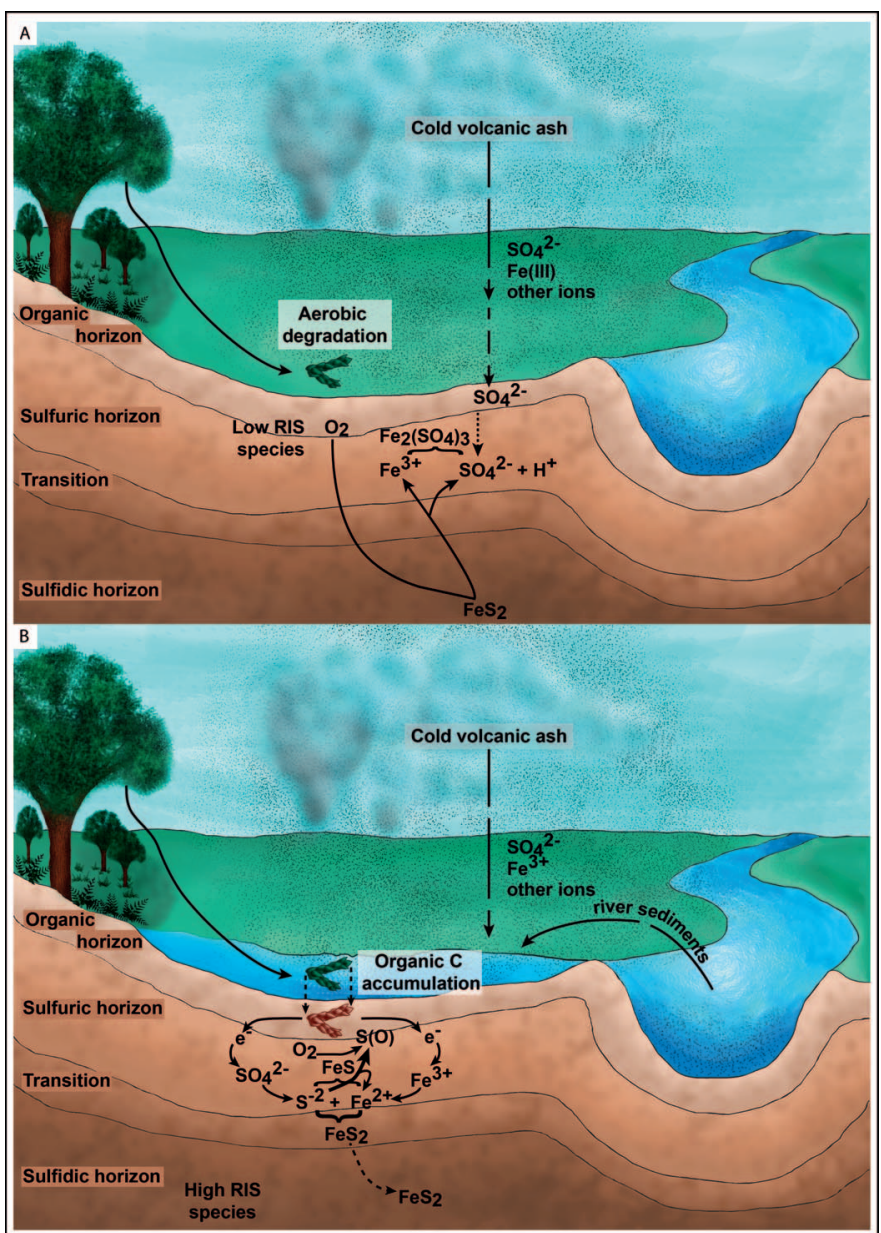

FIG. 9.- Proposed preservation model. Simplified diagrams showing early diagenetic changes at the BTO fossiliferous level affecting the chemical composition of Squamastrobus tigrensis remains. Note parent plants growing in highlands and volcanoes located further away. The model shows chemical reactions (i.e., cyclical changes in iron and sulfur species; following Johnston et al. 2014) as well as the alteration of organic matter. A) Drought phase/ season where sediments contain abundant $\mathrm{Fe}^{3+}$ minerals with predominantly oxic/strongly acidic conditions ( $\mathrm{pH} \approx 3$ to 5) and low concentrations of reduced inorganic sulfur (RIS) in both organic and sulfuric horizons. Some accumulation of $\mathrm{SO}_{4}{ }^{2-}$ in surficial sediments takes place through upward evaporative flux of shallow groundwater solutes and, mainly, by ash fall-supplied $\mathrm{SO}_{4}{ }^{2-}$ minerals. Squamastrobus tigrensis remains are aerobic degraded. B) Flooding phase/ season where mainly sub-oxic/ mildly acidic conditions ( $\mathrm{pH} \approx 5$ to 6.5) prevail. Squamastrobus tigrensis leafy branches decay is partially inhibited because of a rapid burial (river sediments and cold volcanic ash). Thus, slow rates of carbon decomposition promote the accumulation of plant remains $\left(\mathrm{CH}_{2} \mathrm{O}\right)$. The organic matter provides electron donors to drive $\mathrm{SO}_{4}{ }^{2-}$ and $\mathrm{Fe}$ reduction. Partial oxidation leads to reformation of various RIS species (i.e., $\mathrm{FeS}_{2}$ (pyrite), $\mathrm{S}(0)$, and $\mathrm{FeS}$ ), especially in near-surface sediments.

According to the model proposed for the formation of fossilizedcuticles from the Pennsylvanian of the Sydney Coalfield (Nova Scotia; Zodrow and Mastalerz 2009), we consider that the $S$. tigrensis remains are better regarded as fossilized cuticles. That model "presupposes compression-cuticle fossilization under anoxic conditions for late authigenic deposition of sub-micron-sized pyrite on the compressions" (Zodrow and Mastalerz 2009). Here, the vitrinite component (transformed mesophyll) cannot survive oxidizing media, and is poorly represented. On the other hand, these conditions do not affect cuticles; their chemical characteristics are very well preserved. Zodrow and
Mastalerz (2001, 2009) indicated that fossilized cuticles from Sydney were characterized by a generally poor preservation of epidermal features. However, this is in disagreement with the well-preserved epidermal features shown by $S$. tigrensis, such as anticlinal and periclinal walls, subsidiary and guard cells of stomata, and hypodermal cell remains (Fig. 2E-2J). Traceable chemical signatures in plant fossil remains and, consequently the morphological characteristics, can be affected by some depositional settings. Thus, the particularities of the Aptian/volcaniclastic sedimentation, undergone by the $S$. tigrensis remains, protected their cuticles and resulted in unexpected, well-preserved epidermal features. According to Archangelsky et al. (1995), the ash fall might have occurred simultaneously when plants were growing and during the burial of fossil remains.

Proposed Preservation Model and Paleoenvironmental Considerations.- Some authors have suggested that cold volcanic ash may have played a role in the fossilization process that led to the remarkable morphological preservation of the delicate plant tissues characterizing the Baqueró Flora (Archangelsky and Taylor 1986; Cladera and Cuneo 2002). The influence of volcanic activity has been highlighted in several detailed micromorphological studies including foliar cuticles (Archangelsky and Taylor 1986; Archangelsky et al. 1995), imprints of well-preserved fern fronds attached to rhizomes (Carrizo et al. 2011), and charcoalified fern last order pinnules (Villar de Seoane 2001). When volcanic ash is in contact with water, freshly erupted ash produces a solid phase dissolution and a $\mathrm{pH}$ decrease, resulting in increased acidity (e.g., Smithsonian Institution 2000). High acidity of volcanic ash leachates is explained by the presence of aerosols in the plume composed of inorganic acids, such as $\mathrm{H}_{2} \mathrm{SO}_{4}, \mathrm{HCl}$, and HF (e.g., Wilcox 1959; Smithsonian Institution 1997; Cronin and Sharp 2002; Witham et al. 2005; Hoshyaripour et al. 2015). This intense mineral input significantly impacted soil properties and atmospheric conditions and resulted in stressful environmental conditions that probably also influenced plant growth and structure (Archangelsky et al. 1995).

In the present contribution, it is emphasized that the acidic influence was generated by volcanic activity. A simplified conceptual model is proposed, explaining the morphological and chemical preservation of foliar $S$. tigrensis specimens found at the BTO fossiliferous level (Fig. 9). Our model considers different physical and chemical changes that altered the chemical composition of the plant remains, which occurred at different temporal scales and included early- as well as post-diagenetic changes. It is proposed that during early diagenesis, physical and chemical changes were influenced by flood and drought cycles similar to wetland processes today (Johnston et al. 2014). The latter represented a hysteresis in geochemical conditions, providing an explanation for the main biogeochemical changes involving iron and sulfur species that affected the carbon cycle.

According to our model, fragments of the $S$. tigrensis branches were deposited in the floodplain of a braided river system, and the decay of the biological material was partly inhibited because of rapid burial.

The drought event/season (Fig. 9A) was characterized by an almost completely dried floodplain wetland, with predominating strong oxic conditions (estimated at a $\mathrm{pH} \approx 3$ to 5 ). In surficial sediments, some $\mathrm{SO}_{4}{ }^{2-}$ accumulation occurred through (1) the upward evaporative flux of shallow groundwater solutes and, most importantly, by (2) ash fall-supplied $\mathrm{SO}_{4}{ }^{2-}$ minerals, which also increased concentrations of $\mathrm{Fe}^{3+}$ and some other ions (Fig. 9A). Atmospheric exposure of sediments led to the oxidative regeneration of $\mathrm{SO}_{4}{ }^{2-}$ species during dry periods (e.g., Knorr et al. 2009).

Plant remains accumulated during the previous flood event contributed to the formation of the organic horizon, which is the most superficial level. The organic horizon, as well as the sulfuric horizon, contained low concentrations of reduced inorganic sulfur (RIS) species while at some depth in the sulfidic horizon, RIS species were well-represented by mainly pyrite. 
The most important reactions taking place during the drought event/ season involved pyrite oxidation by dissolved oxygen through a series of reactions involving $\mathrm{Fe}^{2+} / \mathrm{Fe}^{3+}$ feedback:

$$
\begin{aligned}
2 \mathrm{FeS}_{2}+7 \mathrm{O}_{2}+2 \mathrm{H}_{2} \mathrm{O} & \rightarrow 2 \mathrm{Fe}^{2+}+4 \mathrm{SO}_{4}{ }^{-2}+4 \mathrm{H}^{+} \\
4 \mathrm{Fe}^{2+}+\mathrm{O}_{2}+4 \mathrm{H}^{+} & \rightarrow 4 \mathrm{Fe}^{3+}+2 \mathrm{H}_{2} \mathrm{O} \\
2 \mathrm{Fe}^{3+}+3 \mathrm{SO}_{4}{ }^{-2} & \rightarrow \mathrm{Fe}_{2}\left(\mathrm{SO}_{4}\right)_{3} \\
\mathrm{SO}_{4}{ }^{2-}+2 \mathrm{H}^{+} & \rightarrow \mathrm{H}_{2} \mathrm{SO}_{4}
\end{aligned}
$$

During the flooding phase/ season (Fig. 9B), freshwater inundation of the floodplains gave rise to new physical-chemical conditions in surficial sediments. Here, microbial respiration caused a relatively rapid decrease in oxygen concentration, and increasing anoxia-favored reducing conditions. As it occurs in today's wetlands, slower rates of organic matter decomposition in sub-oxic, submerged soils promoted the accumulation of plant remains (e.g., Ponnamperuma 1967), implying high concentrations of labile organic carbon in surficial sediments. The accumulation of "oxidable" organic matter in these mildly acidic environments (estimated at a $\mathrm{pH} \approx 5$ to 6.5 ) provided the electron donors to drive $\mathrm{SO}_{4}{ }^{2-}$ and $\mathrm{Fe}^{3+}$ reductions. In addition, the partial oxidation of mainly plant-derived organic matter lead to the reformation of various inorganic sulfur species (i.e., pyrite, $\mathrm{S}(0), \mathrm{FeS}_{2}$, respectively), particularly in near-surface sediments. This situation was in contrast to the original drought conditions that existed before the flooding event, when RIS species were primarily pyrite, which was located at some depth (i.e., sulfidic horizon).

The most important reactions taking place during the flooding phase/ season were as follows:

Ferric ions likely oxidized organic matter to form ferrous ion:

$$
\begin{gathered}
\mathrm{Fe}^{3+}+2 \mathrm{CH}_{2} \mathrm{O} \rightarrow 2 \mathrm{HCO}_{3}{ }^{-}+\mathrm{Fe}^{2+}\left(\text { where } \mathrm{CH}_{2} \mathrm{O}\right. \text { represents, } \\
\text { in a simplified way, plant }- \text { derived organic matter }) .
\end{gathered}
$$

Sulfate ions could have oxidized organic matter to form hydrogen sulfide:

$$
\mathrm{SO}_{4}{ }^{2-}+2 \mathrm{CH}_{2} \mathrm{O} \rightarrow 2 \mathrm{HCO}_{3}{ }^{-}+\mathrm{H}_{2} \mathrm{~S}
$$

Sulfur likely reacted with ferrous iron to form the ferrous iron sulfide mineral pyrite:

$$
\mathrm{Fe}(\mathrm{OH})_{2}+2 \mathrm{~S} \rightarrow \mathrm{FeS}_{2}+\mathrm{H}_{2} \mathrm{O}
$$

Sulfide and ferrous iron led to the formation of pyrite:

$$
2 \mathrm{~S}^{2-}+\mathrm{Fe}^{2+} \rightarrow \mathrm{FeS}_{2}
$$

During the early stages of diagenesis, environmental factors including variable cycles of recurrent ash fall and flood/drought events, greatly influenced the deposition of plant remains. These stages were characterized by relatively unfavorable and changing physicogeochemical conditions which favored the morphological preservation of selected plant taxa, likely those having the most chemically resistant tissues. These tissues had an original chemical composition likely characterized by relatively diagenesis-resistant molecules (e.g., lignin-, resin-, and tannin-related compounds; see Zodrow et al. 2009; D'Angelo and Zodrow 2016, 2018), including a rich aliphatic structure with variable contributions of aromatic and oxygen-containing functionalities.

Overall, the combination of physicogeochemical conditions suggests that a (cyclical) trade-off between preservation and alteration (reduction/ oxidation) of plant organic matter possibly occurred at the BTO fossiliferous level at different times and during different diagenetic phases.

Post-diagenetic changes at the BTO fossiliferous level were probably the result of acidic water infiltration along fractures or permeable rocks, as suggested by the presence of many psammitic and quite permeable members within the Baqueró Group (Archangelsky 1967). Acidic water infiltration would likely have promoted the reactions necessary to further oxidize the mesophyllous-derived vitrinitic component of compressions (which had already suffered some oxidation during early diagenesis), leading to the formation of the $S$. tigrensis fossilized cuticles.

\section{CONCLUSIONS}

For the first time, foliar remains of the podocarp Squamastrobus tigrensis (Coniferales, Lower Cretaceous, Baqueró Group, Santa Cruz, Argentina) are studied by semi-quantitative Fourier transform infrared spectroscopy, followed by data interpretation using principal component analysis. The main conclusions include: (1) Functional groups shown by fossilized-cuticles were very similar to those of cuticles, indicating that the former underwent an oxidization process during burial; (2) The high content of aliphatics and oxygen-containing compounds of both sample types indicated their chemical similarity to type I / II kerogen; (3) PCA of semi-quantitative data showed variability between and within groups representing fossilized-cuticles and cuticles; (4) Information derived from fossil FTIR spectroscopy, host rock analysis, as well as paleoenvironmental, geochemical, taphonomic, and paleobotanical data was used to suggest a preservation model for fossilized-cuticles of $S$. tigrensis. In this model, a combination of early- and post-diagenetic changes is proposed to have taken place at the BTO fossiliferous level; (5) During early diagenesis, physical and chemical changes in organic matter resulted from a rapid burial, anoxic conditions, cold ash fall, and flood and drought cycles, where the latter represented a hysteresis in geochemical conditions involving iron and sulfur species; (6) Post-diagenetic changes at the BTO fossiliferous level likely included acidic water infiltration along fractures or permeable rocks, promoting oxidation of the mesophyllousderived vitrinitic component of compressed plants; and (7) The S. tigrensis remains were influenced by periodic cold ash input, flood (sub-oxic to anoxic conditions) and drought (oxic conditions) cycles, where different physical and chemical changes altered the chemical composition of the $S$. tigrensis remains and their entombing sediments.

The proposed preservation model is a working hypothesis, which is based only on data from the BTO fossiliferous level. Further studies including other stratigraphic levels and different localities (now in progress) are needed to construct a more a generalized model for fossilized-cuticle preservation.

\section{ACKNOWLEDGMENTS}

This research was partially supported by grants ANPCyT-PICT 528/2012 and CONICET PIP 2012/212. We thank Coeditor Gabriela Mángano, the Associate Editor and the reviewers, Vivi Vajda and Cortland Eble, for constructive comments and suggestions that greatly improved the manuscript. We express our special thanks to Orlando Cárdenas for his technical assistance in cuticles and kerogen processing. Gerardo E. Camí (Universidad Nacional de San Luis, San Luis, Argentina) is thankfully acknowledged for his helpful comments and FTIR spectrometry technical assistance. Héctor Villar of GeoLab Sur Laboratory is specially thanked for his valuable help in thermal maturity analysis and palynological characterization of host rock samples as well as for critical reading of the manuscript. We are also grateful to Amalia González for the drawing of Figure 1.

\section{SUPPLEMENTAL MATERIAL}

Data are available from the PALAIOS Data Archive: http://www.sepm.org/pages.aspx?pageid=332.

\section{REFERENCES}

Almendros, G., Dorado, J., Sanz, J., Alvarez-Ramis, C., Fernández-Marrón, M.T., and ArChangelsky, S., 1999, Compounds released by sequential chemolysis from cuticular 
remains of the Cretaceous Gymnosperm Squamastrobus tigrensis (Patagonia, the Argentine): Organic Geochemistry, v. 30, p. 623-634, doi: 10.1016/S0146-6380(99) 00034-0.

Almendros, G. And SAnz, J., 1992, A structural study of alkyl polymers in soil after perborate degradation of humin: Geoderma, v. 53, p. 79-95, doi: 10.1016/0016-7061(92) 90022-Y.

Anderson, T.W., 2003, An Introduction to Multivariate Statistical Analysis: John Wiley and Sons, New Jersey, 752 p.

Archangelsky, S., 1967, Estudio de la Formación Baquero: cretácico inferior de Santa Cruz, Argentina: Revista del Museo de La Plata (nueva serie), Sección Paleontología, v. 5, p. 63-171.

ArChangelsky, S., 1991, Características ultraestructurales de plantas fósiles de Patagonia: Coloquios de Paleontología, v. 43, p. 115-118.

Archangelsky, S., 2003, Flora Cretácica del Grupo Baqueró: Monografías Museo Argentino de Ciencias Naturales "Bernardino Rivadavia", v. 4, 14 p., + CD-ROM

Archangelsky, A., Andreis, R.R., Archangelsky, S., and Artabe, A., 1995, Cuticular characters adapted to volcanic stress in a new Cretaceous cycad leaf from Patagonia, Argentina. Considerations on the stratigraphy and depositional history of the Baqueró Formation: Review of Palaeobotany and Palynology, v. 89, p. 213-233, doi: 10.1016/003 4-6667(95)00011-X.

Archangelsky, S. and Del Fueyo, G.M., 1987, Sobre una Podocarpácea fértil del Cretácico inferior de la provincia Santa Cruz, República Argentina, in S. Archangelsky and G. Del Fueyo (eds.), Sobre una Podocarpacea fértil del Cretacico inferior de la provincia Santa Cruz, Republica Argentina: Actas del VII Simposio Argentino de Paleobotánica y Palinología, p. 85-88.

Archangelsky, S. and Del Fueyo, G.M., 1989, Squamastrobus gen n., a fertile podocarp from the early Cretaceous of Patagonia, Argentina: Review of Palaeobotany and Palynology, v. 59, p. 109-126, doi: 10.1016/0034-6667(89)90010-9.

Archangelsky, S. and Del Fueyo, G.M., 2010, Endemism of Early Cretaceous conifers in Western Gondwana, in C.T. Gee (ed.), Plants in Mesozoic Time: Morphological Innovations, Phylogeny, Ecosystems: Indiana University Press, Indiana, p. 247-268.

ARCHANGELSKY, S. AND TAYLOR, T.N., 1986, Ultrastructural studies of fossil plant cuticles, II, Tarphyderma gen. n., a Cretaceous conifer from Argentina: American Journal of Botany, v. 73 , p. $1577-1587$

ASTM, 2014, D7708-14: Standard test method for microscopical determination of the reflectance of vitrinite dispersed in sedimentary rocks: American Society for Testing and Materials (ASTM) International, West Conshohocken, PA, $10 \mathrm{p}$

BARthel, M., 1962, Epidermisuntersuchungen an einigen inkohlten Pteridospermenblätern des Oberkarbons und Perms: Geologie Beiheft, v. 11, p. 1-140.

Benitez, J., Matas, A.J., And Heredia, A., 2004, Molecular characterization of the plan biopolymer cutin by AFM and spectroscopic techniques: Journal of Structural Biology v. 147, p. 179-184, doi: 10.1016/j.jsb.2004.03.006

Bomfleur, B., Mcloughlin, S., And Vajda, V., 2014, Fossilized nuclei and chromosomes reveal 180 million years of genomic stasis in royal ferns: Science, v. 343, p. 1376-1377, doi: $10.1126 /$ science. 1249884 .

Carrizo, M.A., Del Fueyo, G.M., and Archangelsky, S., 2011, Morfología y anatomía de un helecho creciendo bajo condiciones de estrés en el Aptiano de Santa Cruz, Argentina: Ameghiniana, v. 48, p. 605-617, doi: 10.5710/AMGH.v48i4(474).

Césari, S.N., Limarino, C.O., Llorens, M., Passalía, M.G., Perez Loinaze, V., and Vera, E.I, 2011, High-precision late Aptian U/Pb age for the Punta del Barco Formation (Baqueró Group), Santa Cruz Province, Argentina: Journal of South American Earth Sciences, v. 31, p. 426-431, doi: 10.1016/j.jsames.2011.03.012.

Cladera, G., Andreis, R., Archangelsky, S., and Cúneo, R., 2002, Estratigrafía de Grupo Baqueró, Patagonia (Provincia de Santa Cruz, Argentina): Ameghiniana, v. 39, p. $3-20$.

Cladera, G. and Cúneo, R., 2002, Fossil plants buried by volcanic ash in the Lower Cretaceous of Patagonia, in De Renzi, M. Pardo Alonso, M.V. M. Belinchón, E. Peñalver, P. Montoya, and A. Márquez-Aliaga (eds.), Current Topics on Taphonomy and Fossilization: Ayuntamiento de Valencia, p. 399-403.

Colthup, N.B., Daly, L.H., And Wiberley, S.E., 1990, Introduction to Infrared and Raman Spectroscopy: Academic Press, New York, 511 p.

Corbella, H., 2001, Tuffs of the Baqueró group and the mid-cretaceous frame Extra andean Patagonia, Argentina, in $11^{\circ}$ Congreso Latinoamericano de Geología y $3^{\circ}$ Congreso: Uruguayo de Geología (Montevideo), 6 p. (on CD-ROM).

Cronin, S.J. And Sharp, D.S., 2002, Environmental impacts on health from continuous volcanic activity at Yasur (Tanna) and Ambrym, Vanuatu: International Journal of Environmental Health Research, v. 12, p. 109-123, doi: 10.1080/09603120220129274.

D'ANGelo, J.A., 2004, FT-IR determination of aliphatic and aromatic C-H contents of fossil leaf compressions, part 2: applications: Anuario Latinoamericano de Educación Química, v. 18, p. 34-38.

D'Angelo, J.A., 2006, Analysis by Fourier transform infrared spectroscopy of Johnstonia (Corystospermales, Corystospermaceae) cuticles and compressions from the Triassic of Cacheuta, Mendoza, Argentina: Ameghiniana, v. 43, p. 669-685.

D'Angelo, J.A., Escudero, L.B., Volkheimer, W., And Zodrow, E.L., 2011, Chemometric analysis of functional groups in fossil remains of the Dicroidium flora (Cacheuta, Mendoza, Argentina): implications for kerogen formation: International Journal of Coa Geology, v. 87, p. 97-111, doi: 10.1016/j.coal.2011.05.005.
D'Angelo, J.A. And Marchevsky, E., 2004, FT-IR determination of aliphatic and aromatic $\mathrm{C}-\mathrm{H}$ contents of fossil leaf compressions, part 1: analysis, curve-resolving and choice ofbands: Anuario Latinoamericano de Educación Química, v. 17, p. 37-41.

D'Angelo, J.A. And Zodrow, E.L., 2011, Chemometric study of functional groups in different layers of Trigonocarpus grandis ovules (Pennsylvanian seed fern, Canada): Organic Geochemistry, v. 42, p. 1039-1054, doi: 0.1016/j.orggeochem.2011.06.022.

D'Angelo, J.A. And Zodrow, E.L., 2015, Chemometric study of structural groups in medullosalean foliage (Carboniferous, fossil Lagerstätte, Canada): Chemotaxonomic implications: International Journal of Coal Geology, v. 138, p. 42-54, doi: 10.1016/j. coal.2014.12.003

D'Angelo, J.A. AND Zodrow, E.L., 2016, 3D chemical map and a theoretical life model for Neuropteris ovata var. simonii (index fossil, Asturian, Late Pennsylvanian, Canada): International Journal of Coal Geology, v. 153, p. 12-27, doi: 10.1016/j.coal.2015.11.007.

D'Angelo, J.A. AND Zodrow, E.L., 2018, Fossil cutin of Johnstonia coriacea (Corystospermaceae, Upper Triassic, Cacheuta, Argentina): International Journal of Coal Geology, v. 189, p. 70-74, doi: 10.1016/j.coal.2018.02.016.

D'Angelo, J.A., Zodrow, E.L., AND CAmargo, A., 2010, Chemometric study of functional groups in Pennsylvanian gymnosperm plant organs (Sydney Coalfield, Canada): implications for chemotaxonomy and assessment of kerogen formation: Organic Geochemistry, v. 41, p. 1312-1325, doi: 10.1016/j.orggeochem.2010.09.010.

D'Angelo, J.A., Zodrow, E.L., And Mastalerz, M., 2012, Compression map, functional groups and fossilization: a chemometric approach (Pennsylvanian neuropteroid foliage, Canada): International Journal of Coal Geology, v. 90, p. 149-155, doi: 10.1016/j. coal.2011.11.009.

Del Fueyo, G.M., Villar de Seoane, L., Archangelsky, A., Guler, V., Llorens, M., Archangelsky, S., Gamerro, J.C., Musacchio, E., Passalia, M., and Barreda V., 2007, Biodiversidad de las Paleofloras de Patagonia Austral durante el Cretácico Inferior, in $\mathrm{S}$. Archangelsky, T. Sánchez, and E.P. Tonni (eds.), Ameghiniana Publicación especial $\mathrm{N}^{\circ}$ 11: Asociación Paleontológica Argentina, Buenos Aires, p. 101-122.

DiMichele, W.A., Stein, W.E., and Bateman, R.M., 2001, Ecological sorting of vascular plant classes during the Paleozoic evolutionary radiation, in W.D. Allmon and D.J. Bottjer (eds.), Evolutionary Palaeocology: The Ecological Context of Macroevolutionary Change: Columbia University Press, New York, p. 285-335.

Ganz, H. and Kalkreuth, W., 1987, Application of infrared spectroscopy to the classification of kerogen-types and the evolution of source rock and oil-shale potentials: Fuel, v. 66, p. 708-711, doi: 10.1016/0016-2361(87)90285-7.

Gauglitz, G. And Vo-Dinh, T., 2003, Handbook of Spectroscopy: WILEY-Verlag Chemie Gesellschaft mit beschränkter Haftung and Company Kommanditgesellschaft auf Aktien, Weinheim, $538 \mathrm{p}$.

Guo, Y. And Bustin, R.M., 1998, Micro-FTIR spectroscopy of liptinite macerals in coal: International Journal of Coal Geology, v. 36, p. 259-275, doi: 10.1016/S0166-5162 (97)00044-X.

Guo, Y., Renton, J.J., And Penn, J.H., 1996, FTIR microspectroscopy of particular liptinite(lopinite-) rich, Late Permian coals from southern China: International Journal of Coal Geology, v. 29,, p. 187-197, doi:10.1016/0166-5162(95)00024-0.

Gupta, N.S., Briggs, D.E.G., Collinson, M.E., Evershed, R.P., Michels, R., Jack, K.S., And Pancost, R.D., 2007a, Evidence for the in situ polymerisation of labile aliphatic organic compounds during preservation of fossil leaves: implications for organic matter preservation: Organic Geochemistry, v. 38, p. 499-522, doi:10.1016/j.orggeochem.2006.06.011.

Gupta, N.S., Michels, R., Briggs, D.E.G., Collinson, M.E., Evershed, R.P., and Pancost, R.D., 2007b, Experimental evidence for the formation of geomacromolecules from plant leaf lipids: Organic Geochemistry, v. 38, p. 28-36, doi:10.1016/j.orggeochem.2006.09.014.

Hoshyaripour, G.A., Hort, M., and Langmann, B., 2015, Ash iron mobilization through physicochemical processing in volcanic eruption plumes: a numerical modeling approach: Atmospheric Chemistry and Physics, v. 15, p. 9361-9379, doi: 10.5194/ acp-15-9361-2015.

Hunt, J.H., 1996, Petroleum Geochemistry and Geology: Freeman, New York, 743 p.

Hunt, J.M., Philp, R.P., And Kvenvolden, K.A., 2002, Early developments in petroleum geochemistry: Organic Geochemistry, v. 33, p. 1025-1052, doi: 10.1016/ S0146-6380(02)00056-6.

iCCP (International Committee for Coal Petrology), 1971, International Handbook of Coal Petrography, first supplement: Centre National de la Recherche Scientifique, Paris, unpaginated.

ICCP (International Committee for Coal Petrology), 1975, International Handbook of Coal Petrography, second supplement: Centre National de la Recherche Scientifique, Paris, unpaginated.

iCCP (International Committee for Coal and Organic Petrology), 1998, The new vitrinite classification (ICCP System 1994): Fuel, v. 77, p. 349-358, doi: 10.1016/S0016 2361(98)80024-0.

iCCP (International Committee for Coal and Organic Petrology), 2001, The new inertinite classification (ICCP System 1994): Fuel, v. 80, p. 459-471, doi: 10.1016/S001 6-2361(00)00102-2.

Izenman, A.J., 2008, Modern Multivariate Statistical Techniques: Regression, Classification, and Manifold Learning (Springer Texts in Statistics): Springer, New York, $734 \mathrm{p}$

Johnston, S.G., Burton, E.D., Aaso, T., And Tuckerman, G., 2014, Sulfur, iron and carbon cycling following hydrological restoration of acidic freshwater wetlands: Chemical geology, v. 371, p. 9-26, doi: 10.1016/j.chemgeo.2014.02.001.

Jolliffe, I.T., 2002, Principal Component Analysis: Springer, New York, 487 p 
KAISER, H.F., 1960, The application of electronic computers to factor analysis: Educational and Psychological Measurement, v. 20, p. 141-151.

Kendall, M.G., 1965, A Course in Multivariate Analysis: Charles Griffin and Company Ltd., London, $185 \mathrm{p}$.

Knorr, K.H., Lischeid, G., and Blodau, C., 2009, Dynamics of redox processes in minerotrophic fen exposed to a water table manipulation: Geoderma, v. 153, p. 379-392, doi: 10.1016/j.geoderma.2009.08.023.

LARSEN, J.W., 1988, The macromolecular geochemistry of the coalification process: V.M. Goldschmidt Conference, Baltimore, Maryland, May 11-13, Abstracts, p. 55.

Lattin, J., Carroll, D., and Green, P., 2002, Analyzing Multivariate Data (Duxbury Applied Series): Duxbury Press, California, $185 \mathrm{p}$.

Limarino, C.O., Passalia, M.G., Llorens, M., Vera, E.I., Perez Loinaze, V.S., and Césari, S.N., 2012, Depositional environments and vegetation of Aptian sequences affected by volcanism in Patagonia: Palaeogeography, Palaeoclimatology, Palaeoecology, v. 323, p. 22-41, doi:10.1016/j.palaeo.2012.01.021

Lin, R. AND Ritz, G.P., 1993a, Reflectance FT-IR microspectroscopy of fossil algae contained in organic-rich shale: Applied Spectroscopy, v. 47, p. 265-271.

Lin, R. AND RITZ, G.P., 1993b, Studying individual macerals using IR microspectroscopy, and implications on oil versus gas/condensate proneness and "low-rank" generation: Organic Geochemistry, v. 20, p. 695-706, doi:10.1016/0146-6380(93)90055-G

Lockheart, M.J. van Bergen, P.F., and Evershed, R.P., 2000, Chemotaxonomic classification of fossil leaves from the Miocene Clarkia lake deposit, Idaho, USA based on n-alkyl lipid distributions and principal component analyses: Organic Geochemistry, v. 31, p. 1223-1246, doi: 10.1016/S0146-6380(00)00107-8.

Mastalerz, M. and Bustin, R.M., 1995, Application of reflectance micro-Fourier transform infrared spectrometry in studying coal macerals: comparison with other Fourier transform infrared techniques: Fuel, v.74, p. 536-542, doi: 10.1016/0016-2361 (95)98356-J.

Mastalerz, M. and Bustin, R.M., 1996, Application of reflectance micro-Fourier Transform infrared analysis to the study of coal macerals: an example from the Late Jurassic to Early Cretaceous coals of the Mist Mountain Formation, British Columbia, Canada: International Journal of Coal Geology, v. 32, p. 55-67, doi: 10.1016/S0166-51 62(96)00030-4

Mastalerz, M. and Bustin, R.M., 1997, Variation in chemistry of macerals in coals of the Mist Mountain Formation, Elk Valley coalfield, British Columbia, Canada: International Journal of Coal Geology, v. 33, p. 43-59, doi: 10.1016/S0166-5162(96)00003-1.

Mendonça Filho, J.G., Menezes, T.R., de Oliveira Mendonça, J., de Oliveira, A.D., DA Silva, T.F., Rondon, N.F., AND DA Silva, F.S., 2012, Organic facies: palynofacies and organic geochemistry approaches, in D. Panagiotaras (ed.), Geochemistry-Earth's System Processes, volume 1: InTech, Patras, p. 211-245.

Painter, P.C., Coleman, M.M., Snyder, R.W., Mahajan, O., Komatsu, M., and Walker, JR. P.L., 1981a, Low temperature air oxidation of coking coals: Fourier transform infrared studies: Applied Spectroscopy, v. 35, p. 106-110.

Painter, P.C., Snyder, R.W., Starsinic, M., Coleman, M.M., Kuehn, D.W., and Davis, A., 1981b, Concerning the application of FT-infrared to the study of coal: a critical assessment of band assignments and the application of spectral analysis programs: Applied Spectroscopy, v. 35, p. 475-485

Painter, P.C., Starsinic, M., and Coleman, M.M., 1985, Determination of functional groups in coal by Fourier transform interferometry, in J.R. Ferraro and L.J. Basile (eds.), Fourier Transform Infrared Spectroscopy, volume 4: Academic Press, New York, p. 169-240.

Perez Loinaze, V.S., Vera, E.I., Passalia, M.G. , Llorens, M., Friedman, R., Limarino, C.O., AND CÉSARI, S.N., 2013, High-precision U-Pb zircon age from the Anfiteatro de Ticó Formation: implications for the timing of the early angiosperm diversification in Patagonia: Journal of South American Earth Sciences, v. 48, p. 97-105, doi:10.1016/j. jsames.2013.08.005.

Peters, K.E., Walters, C.C., And Moldowan, J.M., 2005, The Biomarker Guide, volume 1: Cambridge University Press, UK, $1132 \mathrm{p}$

Petersen, H.I. And Nytoft, H.P., 2006, Oil generation capacity of coals as a function of coal age and aliphatic structure: Organic Geochemistry, v. 37, p. 558-583, doi: 10.1016/ j.orggeochem.2005.12.012.

Petersen, H.I., Rosenberg, P., and Nytoft, H.P., 2008, Oxygen groups in coals and alginite-rich kerogen revisited: International Journal of Coal Geology, v.74, p. 93-113, doi: $10.1016 / \mathrm{j}$.coal.2007.11.007.

Ponnamperuma, F.N., Estrella, M.T., and Teresita, L. 1967, Redox equilibria in flooded soils: I, the iron hydroxide systems: Soil Science, v. 103, p. 374-382.

Rochdi, A. AND LANDAIS, P., 1991, Transmission micro-infrared spectroscopy: an efficient tool for micro sample characterization of coal: Fuel, v. 70, p. 367-371, doi: 10.1016/001 6-2361(91)90124-S

Rosenfeld, A. and KaK, A.C., 1982, Digital Picture Processing, volume I: Academic Press, New York, $35 \mathrm{p}$

Shurvell, H.F., 2002, Spectra-structure correlations in the mid- and far-infrared, in J. Chalmers and P. Griffiths (eds.), Handbook of Vibrational Spectroscopy: Sample Characterization and Spectral Data Processing, 3: John Wiley and Sons Ltd., Chichester, p. $1812-1845$.

Smithsonian Institution, 1997, Soufriere Hills: Bulletin of the Global Volcanism Network, v. 22 , p. $2-4$.
Smithsonian Institution, 2000, Copahue: Bulletin of the Global Volcanism Network, v. 25, p. 7-10.

Sobkowiak, M. and Painter, P., 1992, Determination of the aliphatic and aromatic $\mathrm{CH}$ contents of coals by FT-IR: studies of coal extracts: Fuel, v. 71, p. 1105-1125, doi 10.1016/0016-2361(92)90092-3.

Stach, E., Mackowsky, M.T., Teichmüller, M., Teichmüller, R., Taylor, G.H., and ChandRA, D., 1982, Stach's textbook of coal petrology: Gebrüder Borntraeger, Berlin, $535 \mathrm{p}$.

StUART, B., 2004, Infrared Spectroscopy: Fundamentals and Applications: John Wiley and Sons Ltd., UK, 224 p.

Suárez-Ruiz, I, Flores, D., Mendonca Filho, J.G., and Hackley, P.C., 2012, Review an update of the applications of organic petrology: part 1, geological applications: International Journal of Coal Geology, v. 99, p. 54-112, doi: 10.1016/j.coal.2012.02.004

Sýkorová, I., Pickel, W., Christianis, K., Wolf, M., Taylor, G.H., and Flores, D., 2005, Classification of huminite-ICCP System 1994: International Journal of Coal Geology, v 62 , p. $85-106$

Taylor, G.H., Teichmüller, M., Davis, A.C.F.K., Diessel, C.F.K., Littke, R., and Robert, P., 1998, Organic Petrology: Gebrüder Borntraeger, Berlin, 704 p.

TeIchmüller, M., 1989, The genesis of coal from the viewpoint of coal petrology: International Journal of Coal Geology, v. 12 (1-4), p. 1-87.

Tissot, B.P. and Welte, D.H., 1984, Petroleum Formation and Occurrence: Springer Berlin, $538 \mathrm{p}$.

Tyson, R.V., 1995, Sedimentary Organic Matter: Organic Facies and Palynofacies Chapman and Hall, London, 615 p.

Vaida, V., Pucetaite, M., Mcloughlin, S., Engdahl, A., Heimdal, J., and Uvdal, P., 2017, Molecular signatures of fossil leaves provide unexpected new evidence for extinct plan relationships: Nature Ecology and Evolution, v. 1, p. 1093-1099, doi: 10.1038/s41 559-017-0224-5.

VIDRINE, D.W., 2002, Optical Materials for Infrared Spectroscopy, in J. Chalmers and P Griffiths (eds.), Handbook of Vibrational Spectroscopy: Theory and Instrumentation, 1 John Wiley and Sons Ltd., Chichester, p. 398-412.

Villar de Seoane, L., 2001, Estudio cuticular de restos carbonizados del Cretácico Inferior de la Provincia de Santa Cruz, Argentina, in H. Carrizo, J. Carrizo, R. Herbst, and M. de Vergel (eds.), $11^{\circ}$ Simposio Argentino de Paleobotánica y Palinología, Ameghiniana Publicación especial $\mathrm{N}^{\circ}$ 8: Asociación Paleontológica Argentina, Buenos Aires, p. 53-58 WANG, S.H. AND GRIFFITHS, P.R., 1985, Resolution enhancement of diffuse reflectance IR spectra of coals by Fourier self-deconvolution, 1, C-H stretching and bending modes: Fuel, v. 64, p. 229-236, doi: 10.1016/0016-2361(85)90223-6.

WILCox, R.E., 1959, Some effects of recent volcanic ash with special reference to Alaska: United States Geological Survey Bulletin 1028 N, p. 409-476.

Witham, C.S., Oppenheimer, C., AND Horwell, C.J., 2005, Volcanic ash-leachates: a review and recommendations for sampling methods: Journal of Volcanology and Geotherma Research, v. 141, p. 299-326, doi:10.1016/j.jvolgeores.2004.11.010.

Zodrow, E.L., D'Angelo, J.A., AND CleAl, C., 2017, 3D chemometric model and frond architecture of Alethopteris ambigua: implications for reconstruction and taxonomy (Medullosales, Canada): Palaeontographica B, v. 295, p. 91-133, doi: 10.1127/palb/295/ $2017 / 91$.

Zodrow, E.L., D'Angelo, J.A., Helleur, R., And ŠmứneK, Z., 2012, Functional groups and common pyrolysate products of Odontopteris cantabrica (index fossil for the Cantabrian Substage, Carboniferous): International Journal of Coal Geology, v. 100, p. 40-50, doi: 10.1016/j.coal.2011.11.009.

Zodrow, E.L., D’Angelo, J.A., Mastalerz, M., and Keefe, D., 2009, Compression-cuticle of seed ferns: insights from liquid-solid states FTIR (late Palaeozoic-early Mesozoic, Canada-Spain-Argentina): International Journal of Coal Geology, v. 79, p. 61-73, doi: 10.1016/j.coal.2009.06.001

Zodrow, E.L., D'Angelo, J.A., Taylor, W. A. Catelani, T. Heredia-Guerrero, J.A., And Mastalerz, M., 2016, Secretory organs: implications for lipoid taxonomy and kerogen formation (Seed ferns, Pennsylvanian, Canada): International Journal of Coal Geology, v. 167, p. 184-200, doi: 10.1016/j.coal.2016.10.004

Zodrow, E.L. AND MASTALERZ, M., 2001, Chemotaxonomy for naturally macerated tree-fern cuticles (Medullosales and Marattiales), Carboniferous Sydney and Mabou Sub-basins, Nova Scotia, Canada: International Journal of Coal Geology, v. 47, p. 255-275, doi: 10.1016/S0166-5162(01)00045-3

Zodrow, E.L. And Mastalerz, M., 2002, FTIR and py-GC-MS spectra of true-fern and seed-fern sphenopterids (Sydney Coalfield, Nova Scotia, Canada, Pennsylvanian) International Journal of Coal Geology, v. 51, p. 111-127, doi: 10.1016/S0166-5162(02) 00086-1.

Zodrow, E.L. and Mastalerz, M., 2007, Functional groups in a single pteridosperm species: variability and circumscription (Pennsylvanian, Nova Scotia, Canada) International Journal of Coal Geology, v. 70, p. 313-324, doi: 10.1016/j.coal.2006. 06.010 .

Zodrow, E.L. and Mastalerz, M., 2009, A proposed origin for fossilized Pennsylvanian plant cuticles by pyrite oxidation (Sydney Coalfield, Nova Scotia, Canada): Bulletin of Geosciences, v. 84 , p. $227-240$

Received 22 December 2017; accepted 3 May 2018. 